\title{
Synthesis of Metal Nanoparticles by Microorganisms
}

\author{
Yugo Kato and Michio Suzuki * (D) \\ Department of Applied Biological Chemistry, Graduate School of Agricultural and Life Sciences, \\ The University of Tokyo, 1-1-1 Yayoi, Bunkyo-ku, Tokyo 113-8657, Japan; katoh.yugo@gmail.com \\ * Correspondence: amichiwo@mail.ecc.u-tokyo.ac.jp; Tel.: +81-3-5841-5156
}

Received: 11 June 2020; Accepted: 6 July 2020; Published: 8 July 2020

check for updates

\begin{abstract}
Metal nanoparticles (NPs), with sizes ranging from 1-100 nm, are of great scientific interest because their functions and features differ greatly from those of bulk metal. Chemical or physical methods are used to synthesize commercial quantities of NPs, and green, energy-efficient approaches generating byproducts of low toxicity are desirable to minimize the environmental impact of the industrial methods. Some microorganisms synthesize metal NPs for detoxification and metabolic reasons at room temperature and pressure in aqueous solution. Metal NPs have been prepared via green methods by incubating microorganisms or cell-free extracts of microorganisms with dissolved metal ions for hours or days. Metal NPs are analyzed using various techniques, such as ultraviolet-visible spectroscopy, electron microscopy, X-ray diffraction, electron diffraction, energy-dispersive $\mathrm{X}$-ray spectroscopy, and X-ray photoelectron spectroscopy. Numerous publications have focused on microorganisms that synthesize various metal NPs. For example, $\mathrm{Ag}, \mathrm{Au}$, $\mathrm{CdS}, \mathrm{CdSe}, \mathrm{Cu}, \mathrm{CuO}, \mathrm{Gd}_{2} \mathrm{O}_{3}, \mathrm{Fe}_{3} \mathrm{O}_{4}, \mathrm{PbS}, \mathrm{Pd}, \mathrm{Sb}_{2} \mathrm{O}_{3}, \mathrm{TiO}_{2}$, and $\mathrm{ZrO}_{2} \mathrm{NPs}$ have been reported. Herein, we review the synthesis of metal NPs by microorganisms. Although the molecular mechanisms of their synthesis have been investigated to some extent, experimental evidence for the mechanisms is limited. Understanding the mechanisms is crucial for industrial-scale development of microorganism-synthesized metal NPs.
\end{abstract}

Keywords: biosynthesis; metal adsorption; metal nanoparticles; microorganisms

\section{Introduction}

Nanomaterials are of great scientific and commercial interest. Metal nanoparticles (NPs) range in size from about 1-100 nm. Their functions and features differ from those of bulk metals. Notably, the large surface area-to-volume ratio of metal NPs increases opportunities for interactions with other molecules [1]. For example, metal NPs can have antimicrobial, anticancer, catalytic, magnetic, and optical activities and thus have applications in various fields such as medicine, environmental science, and energy [2-4]. The energy state of metal NP electrons differs from that of bulk metals because of the very small particle size. This phenomenon is called the quantum size effect, and it affects the thermal, electromagnetic, and engineering properties of NPs.

Catalytic activity has been reported for $\mathrm{Au}, \mathrm{Ag}, \mathrm{Pd}$, and Pt NPs. The color of solutions of $\mathrm{Au}$ and Ag NPs changes with particle size due to surface electrons that induce surface plasmon resonance (SPR). A solution of Au NPs is red or purple, while that of Ag NPs is yellow or orange. The latter are used in bactericidal, electrical, and medical products, such as for the treatment of skin diseases [5]. $\mathrm{Au}$ NPs attach to DNA fragments, and hence are used to diagnose viral infections [6]. Catalysts and sensors use Pd NPs. For example, Pd NPs are catalysts for Heck and Suzuki reactions [7] and can be used to detect oxygen [8] and formaldehyde [9]. A synergy between Au NPs and Pd NPs is found in core-shell Au-Pd NPs [10], which exhibit catalytic activity toward various reactions, such as oxidation of CO, alcohols, and phenols [11-13]. Pt NPs have antioxidant activities. Pt NPs can act as scavenger 
for superoxide anion radical and hydroxyl radical [14]. Cu NPs are also active as gas-phase catalysts, photocatalysts, and electrocatalysts [15]. $\mathrm{TiO}_{2}$ (Titania) NPs are used in sunscreens because they block ultraviolet (UV) light [16]. They also find applications in cancer chemotherapy and gene delivery because Ti(IV) binds to transferrin in human serum [17]. $\mathrm{Gd}_{2} \mathrm{O}_{3} \mathrm{NPs}$ are superparamagnetic and have high dielectric constants; they are used as imaging agents in magnetic resonance imaging and as phosphors for absorption materials in atomic reactors [18]. Magnetic NPs have many applications. Notably, $\mathrm{Fe}_{3} \mathrm{O}_{4}$ (magnetite) NPs have been used in biomedical applications, such as for anticancer, antitumor, and cell labelling [19]. $\mathrm{ZrO}_{2}$ (zirconia) NPs have high dielectric permittivity, useful optical properties, excellent thermal stability, and chemical inertness. Consequently, they are found in various electronic devices including electrodes, solar cells, and transparent thin films [20]. Semiconductor NPs are called quantum dots. These materials exhibit fluorescence (FL) enhancement that varies with particle size. CdSe NPs, which is a II-VI semiconductor with a hexagonal wurtzite structure, are used in various fields such as optical devices, electronic engineering, and catalysis. They are used in bioimaging to analyze the behavior of cells and molecules in living organisms, and as light-absorbing materials to increase the energy absorption efficiency of solar cells. CdS NPs, which is also a II-VI semiconductor, have many interesting properties [21]. Quantum dots of $\mathrm{PbS}, \mathrm{ZnS}$, and PbSe are used in optoelectronics [22], solar cells [23], and imaging [24].

Chemical and physical methods are used for large-scale synthesis of NPs. For example, Au NPs are prepared by reacting Au ions with citric acid at high temperature and pressure [25]. CdS NPs are prepared by heating dimethylcadmium with sulfur at $300{ }^{\circ} \mathrm{C}$ in an organic solvent such as trioctylphosphine [26]. These methods, which require high pressures, high temperatures, toxic chemical reagents, and organic solvents, are not environmentally friendly, so it is highly desirable to develop new methods that involve low financial and energy costs, and do not generate unwanted byproducts. One popular approach involves the biosynthesis of metal NPs using microorganisms.

Considerable research has explored the relationship between microorganisms and metals. Magnetic bacteria (Spirochaeta plicatilis) with magnetosomes were discovered in 1975 [27]. Magnetosomes contain $\mathrm{Fe}_{3} \mathrm{O}_{4}$ or $\mathrm{Fe}_{3} \mathrm{~S}_{4}$ NPs. Magnetotactic bacteria use these NPs as compasses to detect geomagnetism. Their crystalline polymorphs depend on the bacterial species. Microorganisms produce metal NPs as a survival strategy. Microorganisms can be used to synthesize metal NPs, and there have been many reports of this being accomplished either intra- or extracellularly. Bacterial syntheses of metal NPs are ecofriendly because the processes do not require organic solvents and generate minimal waste at ambient temperature and pressure. Transmission electron microscopy (TEM) images of various metal NPs synthesized by microorganisms are shown in Figure 1.

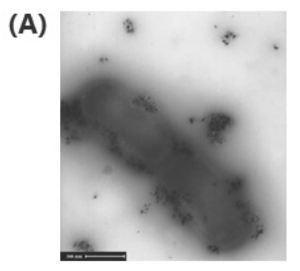

(C)

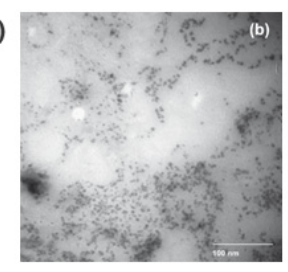

(B)

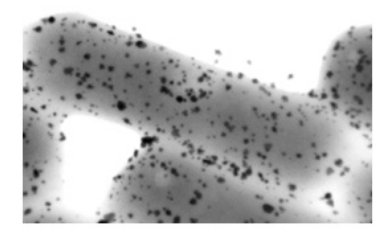

(D)

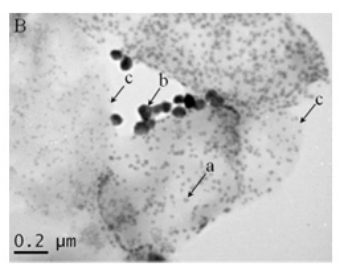

Figure 1. TEM image of microbial synthesized nanoparticles (NPs). (A) Ag NPs [28], (B) Au NPs [29], (C) CdS NPs [18], (D) CdSe NPs [30]. Reproduced with permission from Korbekandi, H. et al., Journal of Chemical Technology \& Biotechnology; published by Wiley, 2012; Prasad, K. and Jha, A.K., Journal of Colloid And Interface Science; published by ELSEVIER, 2010; Ayano, H. et al., Journal of Bioscience and Bioengineering; published by ELSEVIER, 2015. 
NPs containing a zero-valent metal typically require reducing agents for their synthesis. Dispersants must also be used to inhibit particle aggregation. However, most reports of NP synthesis by microorganisms have not provided clear experimental evidence of the organic molecules in microorganisms that function as reductants or dispersants. The identification of the reductants and dispersants is essential to improve the efficiency of metal NP synthesis.

There are two forms of metal NPs synthesis by microorganisms: Outside the cell and inside the cell. When metal NPs were synthesized outside the cells, the extracellular components acted as dispersants; dispersant-capped metal NPs were not aggregated. When the metal NPs synthesized outside the cells were zero-valent metals, the extracellular components and added electron donor or membrane components acted as reductants (Figure 2). However, when metal NPs were synthesized inside the cells, proteins or peptides acted as dispersants. When metal NPs synthesized inside the cells were zero-valent metals, reductants in the cytoplasm provided electrons to the metal ions (Figure 3).

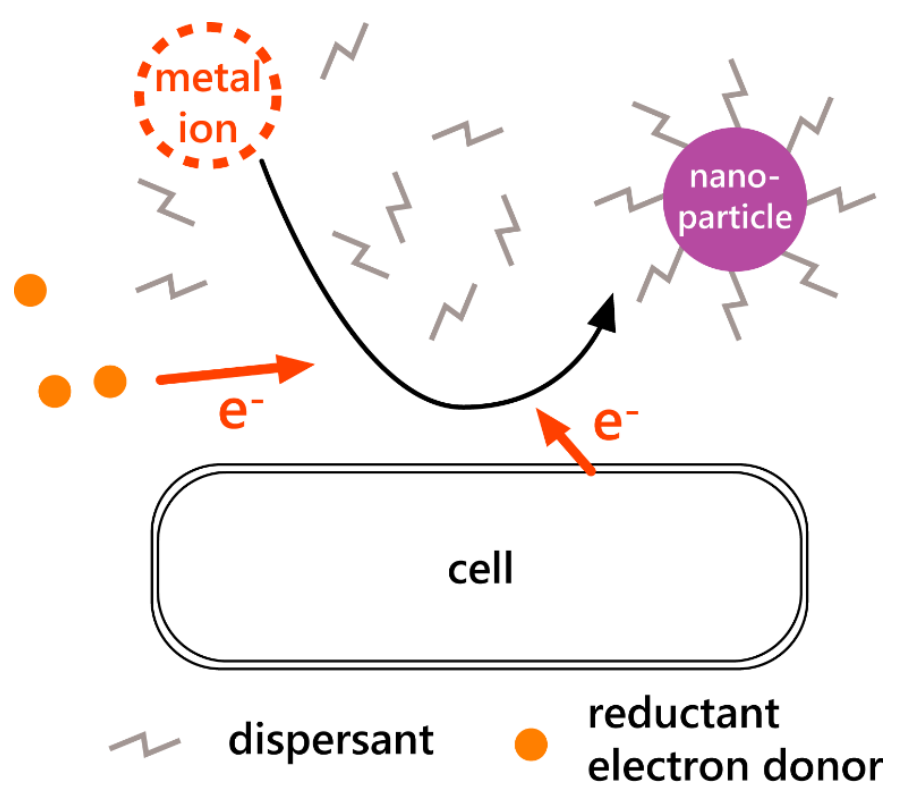

Figure 2. Model of metal nanoparticle synthesis outside cells. Metal ions are reduced by an added electron donor or reductant secreted from the cells. The secreted metabolites outside the cells surround the surface of the NPs and behave as dispersants.

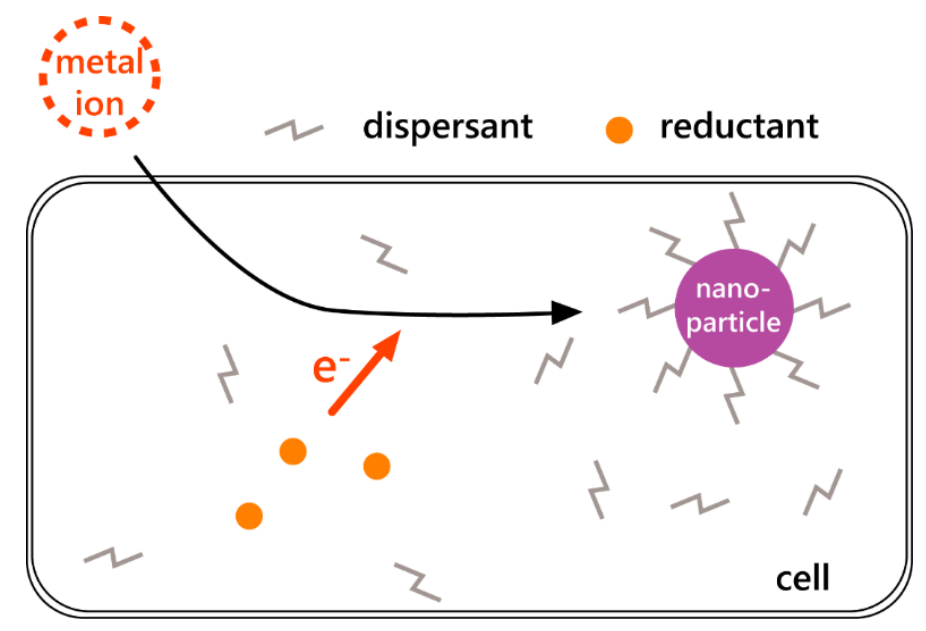

Figure 3. Model of metal nanoparticle synthesis inside cells. Metal ions are reduced by redox enzymes in the cytoplasm. The metabolites inside the cells surround the surface of NPs and behave as dispersants. 
There are two reasons why microorganisms synthesize metal NPs. One reason is to protect themselves from the toxicity of metal ions. Heavy metals are toxic to microorganisms because they inhibit the function of metal enzymes and lead to the generation of reactive oxygen species. Microorganisms use various mechanisms to detoxify heavy metals, e.g., exclusion from cells using transporters, intra-cellular sequestration in vacuoles, and enzymatic detoxification using redox enzymes [31]. The detoxified metals are precipitated as minerals or are preserved in the cells as metal ions [32]. Another reason is to acquire energy; some bacteria use metal ions as electron acceptors [33].

Biosynthetic NPs are prepared by incubating cells with metal salt solutions over periods of minutes to days. Electron donors are sometimes added to the solutions (Figure 4A). To minimize the effects of culture media, cells are washed with sterile water before incubation with metal salt solution to completely remove the culture medium (Figure 4B). Secretions (cell-free extracts (CFEs)) from microorganisms have also been used for the synthesis of metal NPs. Cultured cells were incubated in sterile water for several days, and then the suspension was filtered to obtain the CFE, which was finally mixed with dissolved metal ions in vitro (Figure 4C).

(A)
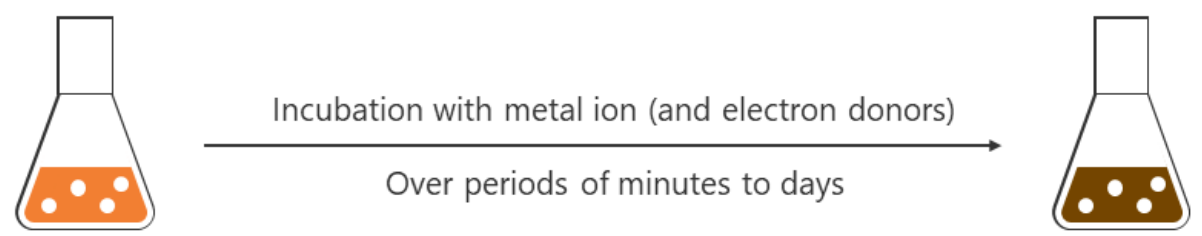

Microbial culture

NPs synthesis

(B)
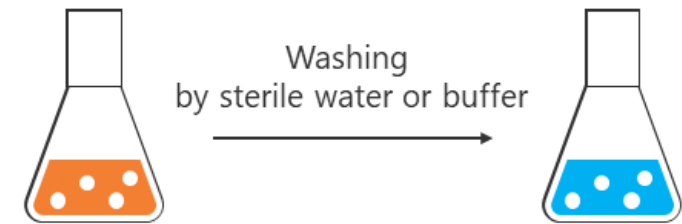

Incubation with metal ion (and electron donors)

Over periods of minutes to days

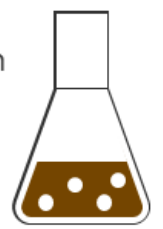

Microbial culture

Microbial suspension

NPs synthesis

(C)
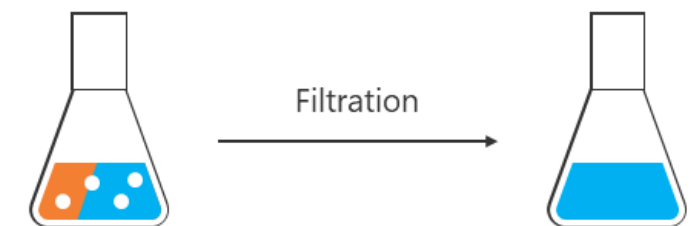

Incubation with metal ion (and electron donors)

Over periods of minutes to days

Microbial culture or suspension

Cell free extraction

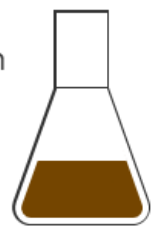

NPs synthesis

Figure 4. Scheme of metal NPs synthesis by microorganisms, (A) NPs synthesis by microbial culture (B) NPs synthesis by washed microbial culture, and (C) NPs synthesis by cell free extracts (CFE).

Various techniques are used to study the properties of metal NPs. These include TEM, scanning electron microscopy (SEM), energy-dispersive X-ray spectroscopy (EDS), UV-visible (UV-vis) spectrometry, FL spectrometry, dynamic light scattering (DLS), X-ray diffraction (XRD), and X-ray photoelectron spectroscopy (XPS).

TEM and SEM provide details about the shape, size, and localization of metal NPs [34,35], while EDS reveals their elemental composition [36]. As noted above, some solutions of noble-metal NPs are distinctly colored. Ultraviolet-visible [17] and FL spectroscopies are also used to characterize metal NPs such as size and shape. The wavelength of an absorption maximum depends on the NP particle size and metal species. The size distribution of metal NPs can be determined by DLS techniques [37], while XRD is used to identify crystalline polymorphs, and with the use of Scherrer's equation, this can yield estimates of their average size [19]. XPS provides details of the chemical bonding state of metal NPs [38]. 
This review summarizes the NPs synthesis by microorganisms in terms of biomineralizaion of microorganisms. Although many previous reviews about metal NPs by microorganisms focused on the species of microorganisms, our review categorizes the kinds of metals. We summarize reports of NPs synthesis by microorganisms in Section 2. We also note that the molecular mechanisms of metal NPs synthesis in microorganisms are important to increase the efficiency of metal NPs synthesis. The metabolites related to the molecular mechanisms reported in many publications are introduced in Section 3. As it is better to cultivate easily the microorganisms for use of application, this review shows only the microorganisms that grew in general medium and under normal temperature and pressure. Microorganisms such as anaerobes, thermophiles, acidophiles, alkaliphiles, halophiles, and polyextremophiles do so-called extreme conditions are not referred in this review.

\section{Nanoparticle Synthesis by Microorganisms}

\subsection{Silver Nanoparticles}

Table 1 lists the strains of microorganism that have been used for the synthesis of Ag NPs and the techniques used for their study.

Table 1. List of microorganisms for synthesis of Ag nanoparticles and technique for confirmation of Ag nanoparticles.

\begin{tabular}{|c|c|c|c|c|c|c|}
\hline Metal & Microorganism & Classification & $\begin{array}{c}\text { Active } \\
\text { Molecules }\end{array}$ & $\begin{array}{l}\text { Size } \\
(\mathrm{nm})\end{array}$ & $\begin{array}{c}\text { Techniques } \\
\text { Used for } \\
\text { Detection }\end{array}$ & Ref. \\
\hline $\mathrm{Ag}$ & $\begin{array}{c}\text { Pseudomonas stutzeri } \\
\text { AG259 }\end{array}$ & bacteria & & $20-100$ & TEM, UV-vis & [34] \\
\hline $\mathrm{Ag}$ & Fusarium oxysporum & fungi & & $5 \sim 15$ & TEM, UV-vis & [39] \\
\hline $\mathrm{Ag}$ & $\begin{array}{c}\text { Lactobacillus casei } \\
\text { subsp. Casei DSM } 20011\end{array}$ & bacteria & & $25-50$ & TEM, UV-vis & [28] \\
\hline $\mathrm{Ag}$ & $\begin{array}{l}\text { Escherichia coli } \\
\text { K12 }\end{array}$ & bacteria & $\begin{array}{l}\text { hemiacetal } \\
\text { groups } \\
\text { of sugars }\end{array}$ & $10-30$ & $\begin{array}{l}\text { TEM, EDS, } \\
\text { UV-vis, XPS }\end{array}$ & [36] \\
\hline $\mathrm{Ag}$ & $\begin{array}{l}\text { Lactobacillus acidophilus } \\
58 \mathrm{p}\end{array}$ & bacteria & & ca. 30.7 & TEM, UV-vis & [40] \\
\hline $\mathrm{Ag}$ & $\begin{array}{l}\text { Lactobacillus plantarum } \\
92 \mathrm{~T}\end{array}$ & bacteria & & ca. 20.0 & TEM, UV-vis & [40] \\
\hline $\mathrm{Ag}$ & $\begin{array}{l}\text { Lactobacillus delbrueckii } \\
\text { subsp. Bulgaricus }\end{array}$ & bacteria & & $1.4-8.9$ & $\begin{array}{l}\text { TEM, UV-vis, } \\
\text { XRD }\end{array}$ & [41] \\
\hline
\end{tabular}

Pseudomonas stutzeri AG259 bacterium, which was isolated from a silver mine, accumulated silver by forming Ag-containing NPs. Triangular, hexagonal, and spheroidal NPs were observed by TEM. UV-vis spectrum showed optical function of Ag-containing nanoparticles [34].

Fusarium oxysporum synthesized Ag NPs. An $\mathrm{AgNO}_{3}$ solution was added to a suspension of F. oxysporum in the dark. The selected-area diffraction (SAED) pattern of the NPs revealed that the Ag particles were crystalline [39].

Lactobacillus casei subsp. casei (DSM 20011) also synthesized Ag NPs. An $\mathrm{AgNO}_{3}$ solution was added to $L$. casei cells with glucose. The optimal synthetic conditions were as follows: $4.64 \mathrm{~g} / \mathrm{L}$ of biomass, $56 \mathrm{mmol} / \mathrm{L}$ of glucose as an electron donor, and $0.1 \mathrm{mmol} / \mathrm{L}$ of $\mathrm{AgNO}_{3}$ [28].

Ag NPs were also synthesized by adding $\mathrm{AgNO}_{3}$ to an Escherichia coli $\mathrm{K} 12$ culture solution. Lattice-fringe fingerprinting of Ag NPs was completed using high-resolution TEM (HR-TEM) [36].

Garmasheva et al. reported the synthesis by certain Lactobacillus species. Ag NPs were prepared by incubating cells washed by sterile water with $\mathrm{AgNO}_{3}$. The Ag NPs synthesized by L. acidophilus 58p 
and by L. plantarum $92 \mathrm{~T}$ exhibited antimicrobial activity. Moreover, NPs synthesized by L. acidophilus $58 \mathrm{p}$ were more active than L. plantarum $92 \mathrm{~T}$ against some bacteria [40].

Extracts of Lactobacillus delbrueckii subsp. Bulgaricus isolated from kindrimo (locally fermented milk) from settlements of Fulani nomadic herdsmen of Kano State, Nigeria were used to prepare Ag NPs. Under sunlight irradiation, the L. delbrueckii extract was mixed with $\mathrm{AgNO}_{3}$ solution. Sunlight irradiation was essential for the synthesis [41].

\subsection{Au Nanoparticles}

Table 2 lists the microorganism strains used for the synthesis of Au NPs and the techniques used for their study.

Incubating Verticillium sp. (AAT-TS-4) with $\mathrm{HAuCl}_{4}$ formed Au NPs. TEM observations of thin sections of the cells revealed that the NPs were present on the cell wall (outer boundary) and on the cytoplasmic membrane [7].

$\mathrm{Au}$ NPs were also synthesized using Rhodococcus sp. and an alkalotolerant actinomycete. The bacterium was isolated from fig trees from the Pune district of Maharashtra, India. TEM of ultrathin sections of cells containing the Au NPs established that the particles were located in the cell wall and the cytoplasmic membrane. Notably, there were more NPs in the cytoplasmic membrane. Biosynthesis of the Au NPs did not hinder bacterial multiplication [35].

$\mathrm{Au}$ NPs were also synthesized on the surface of E. coli DH5 $\alpha$. TEM observations revealed that the NPs were mostly spherical [42].

Rhodopseudomonas capsulate was also used to synthesize Au NPs. The synthesis was $\mathrm{pH}$-dependent, and spherical Au NPs were observed at $\mathrm{pH} 7$ by TEM [43]. Furthermore, CFEs from R. capsulate also synthesized Au NPs. The shape of the NPs depended on the Au ion concentration. At lower concentrations, spherical Au NPs were synthesized, while Au nanowires were synthesized at higher concentrations [44].

$\mathrm{Au}$ NPs were synthesized by Shewanella algae, which is an iron-reducing bacterium. The synthesis was very rapid, with reduction of gold ions occurring within $30 \mathrm{~min}$. The similarity of the reduction potentials of the Fe(III) and noble-metal ions enabled the synthesis of the Au NPs [33,45].

$\mathrm{Au}$ NPs were synthesized using the culture supernatant of Aspergillus niger NCIM 616. The mycelial mass of $A$. niger NCIM616 was washed with Milli-Q water and incubated in deionized water. The culture supernatant was obtained by filtration. TEM revealed that adding $\mathrm{AuCl}_{3}$ solution to the culture supernatant produced NPs [46].

Cupriavidus metallidurans $\mathrm{CH} 34$, which forms biofilms on Au grains, accumulated $\mathrm{Au}(\mathrm{III})$ complex. Synthesized Au NPs were located in the cytoplasm, suggesting cytoplasmic reduction. Micro X-ray FL analysis established that the NPs were localized within the cell envelope [47].

High-resolution TEM observations revealed that Au NPs with an average diameter of $10 \mathrm{~nm}$ were synthesized by incubating a suspension of Rhizopus oryzae MTCC 262 with $\mathrm{HAuCl}_{4}$. The particles were located on the cell membrane. Atomic force microscopy (AFM) revealed morphological changes of the nanogold-bioconjugate (NGBC) after adsorption of organophosphorus pesticides. This NGBC also exhibited highly antibacterial activity [48].

$\mathrm{Au}$ nanocubes were synthesized using Bacillus licheniformis. The nanocubes observed by SEM ranged in size from 10-100 $\mathrm{nm}$. Based on UV-vis spectroscopy and XRD, their average diameter was determined to be 67 and $25.48 \mathrm{~nm}$, respectively [49].

$\mathrm{Au}$ NPs were synthesized by Stenotrophomonas maltophila AuRed02 isolated from gold-enriched soil. Cryo-TEM observations revealed that the NPs were located on the inner cytoplasmic membrane [50].

Au NPs were also synthesized by Hormoconis resinae MTCC 368 isolated from soil samples collected near a refinery situated at Mathura, India. The size of the NPs observed using HR-TEM ranged from 3-20 nm. NPs extracted by centrifugation were used in the analyses [51].

Marinobacter sp. RS11 was isolated from water sampled from a solar saltern at Kakinada, India. $16 \mathrm{~S}$ rRNA gene sequences revealed that this bacterium resembled Marinobacter pelagius JCM 14804. 
RS 11 was able to synthesize Au NPs. Dynamic light scattering measurements of the NPs revealed that most of the particles were smaller than $10 \mathrm{~nm}$ [52].

Lactobacillus kimchicus DCY51T bacterium isolated from Korean kimchi synthesized spherical Au NPs with sizes ranging from 5-30 nm. These NPs were highly stable in physiological buffer and biological media, and had an average crystallite size of $13 \mathrm{~nm}$. They were better free-radical scavengers than the corresponding gold salt against 2, 2-diphenyl-1-picrylhydrazyl (DPPH) [53].

Delftia acidovorans isolated from gold nugget microbiota. In the microbiota, Au nanoparticles ranging from 10-200 $\mathrm{nm}$ in size were existed by D. acidovorans. D. acidovorans synthesized Au nanoparticles to protect itself from toxic soluble $\mathrm{Au}^{3+}$ ions. When D. acidovorans was grown on an agar plate in the presence of $\mathrm{Au}^{3+}$ ions, darkened zones developed around the colonies, indicating that D. acidovorans generated reducing substances [54].

Streptomyces sp. NK52 (KCTC 19739) was isolated from a laundry spot favoring alkalophiles near Pune, India. The cell-free supernatant of Streptomyces sp. NK52 obtained by centrifugation was used for the synthesis of the Au NPs with sizes ranging from 10-100 nm. Various shapes of NPs were observed, including triangles, rods, spheres, hexagonal prisms, rhomboids, and rectangular nanoplates [55].

$\mathrm{Au}$ NPs were synthesized by Azospirillum brasilense Sp245. The size of the NPs ranged from 5-50 nm [37].

The thermophilic bacterium Thermus scotoductus SA-01 also synthesized Au NPs. This bacterium is unique to South Africa and can reduce Fe(III), Mn(IV), Co(III)-EDTA, Cr(VI), and U(VI) through dissimilar pathways. Observations of ultrathin sections by TEM revealed that the Au NPs were located on the outer wall layer [56].

$\mathrm{Au}$ NPs were also synthesized by the cell-free filtrate of Bacillus niabensis 45 , although details were not provided [57].

Serratia marcescens was isolated from a damp area at the Sheda Science and Technology Complex in Abuja, Nigeria. The bacterial colony was red-colored. Au NPs were synthesized by incubating the biomass or CFE of $S$. marcescens with $\mathrm{HAuCl}_{4}$. Au NPs synthesis was $\mathrm{pH}$-dependent: TEM observations established that smaller NPs were synthesized at lower $\mathrm{pH}$ [58].

Au NPs were synthesized by Lactobacillus casei JCM 1134 by incubating cells washed by distilled water in $\mathrm{KAuCl}_{4}$ solution. Cryo-SEM revealed that the NPs were localized outside the cell membrane. Smaller Au NPs were synthesized using the CFE [29,59].

A CFE from Bacillus marisflavi YCIS MN 5 isolated from estuarine water at Dabhol, India was used to synthesize Au NPs. The spherical Au NPs were catalytically active for the reduction of Congo red and methylene blue dyes. Gas chromatography-mass spectrometry of the degraded products revealed the formation of $\alpha$-naphthylamine and phthalic acid from the Congo red dye and 2-methyl benzothiazole from the methylene blue dye [60].

Table 2. List of microorganisms for synthesis of Au nanoparticles and technique for confirmation of Au nanoparticles.

\begin{tabular}{|c|c|c|c|c|c|c|}
\hline Metal & Microorganism & Classification & $\begin{array}{c}\text { Active } \\
\text { Molecules }\end{array}$ & $\begin{array}{l}\text { Size } \\
(\mathrm{nm})\end{array}$ & $\begin{array}{l}\text { Techniques Used for } \\
\text { Detection }\end{array}$ & Ref. \\
\hline $\mathrm{Au}$ & $\begin{array}{l}\text { Verticillium sp. } \\
\text { AAT-TS-4 }\end{array}$ & Bacteria & & ca. 20 & $\begin{array}{c}\text { TEM, SEM, EDS, UV-vis, } \\
\text { XRD }\end{array}$ & [7] \\
\hline $\mathrm{Au}$ & Rhodococcus sp. & Bacteria & & $5-15$ & TEM, UV-vis, XRD & [35] \\
\hline $\mathrm{Au}$ & $\begin{array}{l}\text { Escherichia coli } \\
\text { DH5 } \alpha\end{array}$ & Bacteria & & ca. 25 & $\begin{array}{l}\text { TEM, SEM, UV-vis, XRD } \\
\text { cyclic voltammograms }\end{array}$ & [42] \\
\hline $\mathrm{Au}$ & Rhodopseudomonas capsulata & Bacteria & NADH & $10-20$ & TEM, UV-vis, XRD & [43] \\
\hline $\mathrm{Au}$ & Shewanella algae & Bacteria & & $10-20$ & TEM, EDS, XANES & $\begin{array}{l}33, \\
45]\end{array}$ \\
\hline $\mathrm{Au}$ & $\begin{array}{l}\text { Rhodopseudomonas capsulata } \\
\text { (CFE) }\end{array}$ & Bacteria & & $10-21$ & TEM, EDS, UV-vis & [44] \\
\hline
\end{tabular}


Table 2. Cont.

\begin{tabular}{|c|c|c|c|c|c|c|}
\hline Metal & Microorganism & Classification & $\begin{array}{c}\text { Active } \\
\text { Molecules }\end{array}$ & $\begin{array}{l}\text { Size } \\
(\mathrm{nm})\end{array}$ & $\begin{array}{l}\text { Techniques Used for } \\
\text { Detection }\end{array}$ & Ref. \\
\hline $\mathrm{Au}$ & $\begin{array}{l}\text { Aspergillus niger } \\
\text { NCIM } 616\end{array}$ & Fungi & protein & $\begin{array}{c}\text { ca. } \\
12.8\end{array}$ & $\begin{array}{l}\text { TEM, SEM, UV-vis, XRD } \\
\text { Zeta potential measurement }\end{array}$ & [46] \\
\hline $\mathrm{Au}$ & $\begin{array}{l}\text { Cupriavidus metallidurans } \\
\text { CH34 }\end{array}$ & Bacteria & & 100 & $\begin{array}{c}\text { TEM, SEM, EDS, XANES, } \\
\mu \text { XRF }\end{array}$ & [47] \\
\hline $\mathrm{Au}$ & $\begin{array}{l}\text { Rhizopus oryzae } \\
\text { MTCC } 262\end{array}$ & fungi & & 10 & TEM, EDS, UV-vis, AFM & [40] \\
\hline $\mathrm{Au}$ & Bacillus licheniformis & bacteria & & $10-100$ & SEM, UV-vis, XRD & [49] \\
\hline $\mathrm{Au}$ & $\begin{array}{c}\text { Stenotrophomonas maltophilia } \\
\text { AuRed02 }\end{array}$ & bacteria & NADPH & 40 & TEM, SEM, EDS, UV-vis & [50] \\
\hline $\mathrm{Au}$ & $\begin{array}{c}\text { Hormoconis resinae } \\
\text { MTCC } 368\end{array}$ & Fungi & & $3-20$ & TEM, EDS, UV-vis, XRD & [51] \\
\hline $\mathrm{Au}$ & $\begin{array}{l}\text { Marinobacter sp. } \\
\quad \text { RS11 }\end{array}$ & bacteria & & $<10$ & TEM, SEM, UV-vis, DLS & {$[52]$} \\
\hline $\mathrm{Au}$ & $\begin{array}{l}\text { Lactobacillus kimchicus } \\
\text { DCY51 }\end{array}$ & bacteria & $\begin{array}{l}\text { amino acid } \\
\text { residues } \\
\text { surface-bound } \\
\text { proteins }\end{array}$ & $5 \sim 30$ & $\begin{array}{c}\text { TEM,, EDS, UV-vis, XRD, } \\
\text { DLS }\end{array}$ & [53] \\
\hline $\mathrm{Au}$ & Delftia acidovorans & bacteria & Delftibactin & N.D. & TEM, UV-vis & [54] \\
\hline $\mathrm{Au}$ & $\begin{array}{l}\text { Streptomyces sp. } \\
\text { NK52 }\end{array}$ & bacteria & & $10-100$ & SEM, UV-vis, XRD & [55] \\
\hline $\mathrm{Au}$ & $\begin{array}{l}\text { Azospirillum brasilense } \\
\text { Sp245 }\end{array}$ & bacteria & & $5-50$ & TEM, UV-vis, DLS & [37] \\
\hline $\mathrm{Au}$ & $\begin{array}{l}\text { Thermus scotoductus } \\
\text { SA-01 }\end{array}$ & bacteria & $\mathrm{ABC}$ transporter & $<50$ & TEM, EDS, UV-vis, XRD & [56] \\
\hline $\mathrm{Au}$ & Bacillus niabensis 45 & bacteria & cyclic peptide & N.D. & $\begin{array}{c}\text { TEM, SEM, EDS, UV-vis, } \\
\text { XRD }\end{array}$ & [57] \\
\hline $\mathrm{Au}$ & Serratia marcescens & bacteria & prodigiosin & $20-120$ & $\begin{array}{c}\text { TEM, SEM, EDS, UV-vis, } \\
\text { XRD } \\
\text { DLS, XPS, He ion } \\
\text { microscopy }\end{array}$ & {$[58]$} \\
\hline $\mathrm{Au}$ & $\begin{array}{l}\text { Lactobcills casei } \\
\text { JCM1134 }\end{array}$ & bacteria & $\begin{array}{c}\text { DGDG/lactic } \\
\text { acidlacto-N-triose }\end{array}$ & $\begin{array}{c}\text { ca. } \\
29.6\end{array}$ & $\begin{array}{c}\text { TEM, SEM, EDS, UV-vis, } \\
\text { XRD }\end{array}$ & $\begin{array}{l}{[29,} \\
59]\end{array}$ \\
\hline $\mathrm{Au}$ & $\begin{array}{l}\text { Bacillus marisflavi } \\
\text { YCIS MN } 5\end{array}$ & bacteria & protein & $\begin{array}{r}\text { ca. } \\
13.5\end{array}$ & $\begin{array}{l}\text { TEM, SEM, UV-vis, XRD, } \\
\text { DLS }\end{array}$ & [60] \\
\hline
\end{tabular}

\subsection{Cadmium Sulfide Nanoparticles}

Table 3 lists the microorganism strains used for the synthesis of CdS NPs and the techniques used for their study.

Table 3. List of microorganisms for synthesis of CdS nanoparticles and technique for confirmation of CdS nanoparticles.

\begin{tabular}{ccccccc}
\hline Metal & Microorganism & Classification & $\begin{array}{c}\text { Active } \\
\text { Molecules }\end{array}$ & $\begin{array}{c}\text { Size } \\
\text { (nm) }\end{array}$ & $\begin{array}{c}\text { Techniques Used } \\
\text { for Detection }\end{array}$ & Ref. \\
\hline CdS & $\begin{array}{c}\text { Escherichia coli } \\
\text { ABLE C }\end{array}$ & bacteria & $2-5$ & TEM, EDS, STEM & {$[61]$} \\
\hline CdS & $\begin{array}{c}\text { Rhodopseudomonas } \\
\text { palustris }\end{array}$ & bacteria & $\begin{array}{c}\text { cysteine } \\
\text { desulfhydrase }\end{array}$ & ca. 8.0 & $\begin{array}{c}\text { TEM, UV-vis, XRD, } \\
\text { FT-IR, SAED }\end{array}$ & {$[62]$} \\
\hline $\mathrm{CdS}$ & Lactobacillus sp & bacteria & & ca. 4.9 & TEM, XRD, UV-vis & {$[18]$} \\
\hline $\mathrm{CdS}$ & Sachharomyces cerevisae & bacteria & & ca. 3.6 & TEM, XRD, UV-vis & {$[18]$} \\
\hline
\end{tabular}


CdS NPs were synthesized by incubating the E. coli strain ABLE C with $\mathrm{CdCl}_{2}$ and $\mathrm{NaS}$. Scanning TEM observations revealed the presence of CdS NPs in the cells. Electron diffraction patterns confirmed they had a wurtzite crystal structure [61].

CdS NPs were synthesized by incubating washed Rhodopseudomonas palustris cells in phosphate-buffered saline containing $\mathrm{CdSO}_{4}$. SAED revealed that the NPs was polycrystalline cubic CdS. UV-vis absorption at $425 \mathrm{~nm}$ showed that $R$. palustris cells in the stationary phase synthesized more CdS NPs than the cells in the mid- or late-logarithmic phase [62].

Lactobacillus sp. synthesized CdS NPs. After adding solutions of $\mathrm{CdCl}_{2}$ and $\mathrm{H}_{2} \mathrm{~S}$ to a dilute Lactobacillus sp. solution, the mixture was steam-heated. The solution was incubated at room temperature overnight. The polymorphism of the crystalline CdS NPs was investigated using XRD. Surface plasmon resonance was observed at $393 \mathrm{~nm}$ in the UV-vis spectrum. The estimated bandgap energy was $2.52 \mathrm{eV}[18]$.

Cadmium sulfide NPs were synthesized by the yeast Saccharomyces cerevisiae, but the strain was not described. Cells were removed by filtration and diluted with 30\% ethanol. After culturing, aqueous solutions of $\mathrm{CdCl}_{2}$ and $\mathrm{H}_{2} \mathrm{~S}$ were added to the yeast solution; the combined solution was then heated at $60^{\circ} \mathrm{C}$ for $10-20 \mathrm{~min}$ in a steam bath. The solution was cooled and incubated overnight at room temperature. Surface plasmon resonance was observed at $369 \mathrm{~nm}$ in the UV-vis spectrum. The estimated bandgap energy was $2.607 \mathrm{eV}$ [18].

\subsection{Cadmium Selenide Nanoparticles}

Table 4 lists the microorganism strains used for the synthesis of CdSe NPs and the techniques used for their study.

Table 4. List of microorganisms for synthesis of CdSe nanoparticles and technique for confirmation of CdSe nanoparticles.

\begin{tabular}{ccccccc}
\hline Metal & Microorganism & Classification & $\begin{array}{c}\text { Active } \\
\text { Molecules }\end{array}$ & $\begin{array}{c}\text { Size } \\
(\mathbf{n m})\end{array}$ & $\begin{array}{c}\text { Techniques Used } \\
\text { for Detection }\end{array}$ & Ref. \\
\hline CdSe & $\begin{array}{c}\text { Saccharomyces } \\
\text { cerevisiae } \\
\text { BY4742 }\end{array}$ & fungi & NADPH & $2.69-6.34$ & $\begin{array}{c}\text { TEM, FL, } \\
\text { laser confocal } \\
\text { scanning microscop }\end{array}$ & [63] \\
\hline CdSe & $\begin{array}{c}\text { Helminthosporum } \\
\text { solani }\end{array}$ & bacteria & & ca. 5.5 & $\begin{array}{c}\text { TEM, EDS, UV-vis, } \\
\text { FL, XPS }\end{array}$ & [64] \\
\hline CdSe & $\begin{array}{c}\text { Saccharomyces } \\
\text { cerevisiae } \\
\text { ATCC9763 }\end{array}$ & fungi & protein & 15 to 20 & $\begin{array}{c}\text { TEM, EDS, FL } \\
\text { laser scanning } \\
\text { confocal microscope }\end{array}$ & [65] \\
\hline CdSe & $\begin{array}{c}\text { Pseudomonas } \\
\text { aeruginosa } \\
\text { strain RB }\end{array}$ & bacteria & & $10 / 70-100$ & TEM, EDS & [30] \\
\hline CdSe & $\begin{array}{c}\text { Fusarium oxysporum } \\
\text { JCM11502 }\end{array}$ & fungi & $\begin{array}{c}\text { superoxide } \\
\text { dismutase }\end{array}$ & $8-28$ & TEM, EDS, FL & [66] \\
\hline
\end{tabular}

Saccharomyces cerevisiae BY4742 was co-incubated with $\mathrm{Na}_{2} \mathrm{SeO}$, and then transported into a fresh culture with $\mathrm{CdCl}_{2}$ in the dark to synthesize CdSe NPs. Additionally, in situ TEM observations revealed that the FL resulted from intracellular CdSe nanocrystals [63].

Helminthosporum solani, which is a plant pathogenic fungus, was incubated with an aqueous solution of $\mathrm{CdCl}_{2}$ and $\mathrm{SeCl}_{4}$ to produce CdSe NPs. The UV-vis spectrum had an absorbance band centered at $350 \mathrm{~nm}$, and excitation at $380 \mathrm{~nm}$ resulted in an emission band centered at $430 \mathrm{~nm}$ in the FL spectrum, suggesting the formation of CdSe quantum dots. Monodispersed spherical NPs and a few cube-shaped particles were observed outside the cells. The EDS spectrum revealed the presence of Cd and Se, and XPS measurements suggested that the NPs were encapsulated by proteinaceous materials [64]. 
Saccharomyces cerevisiae ATCC9763 was also used to prepare CdSe NPs. The maximum FL intensity of bacterial solutions containing CdSe NPs was used to determine the optimal reaction condition, i.e., culturing $S$. cerevisiae with $5 \mathrm{mM} \mathrm{Na}_{2} \mathrm{SeO}_{3}$ for $22 \mathrm{~h}$ and $1 \mathrm{mM} \mathrm{CdCl}_{2}$ for $26 \mathrm{~h}$ incubation. The MTT assay, which is a standard cell viability assay, and morphology observations revealed that the cytotoxicity of S. cerevisiae ATCC9763-prepared CdSe NPs was lower than that of thioglycolic acid (TGA)-capped CdSe and TGA-capped CdTe [65].

CdSe NPs were synthesized by Pseudomonas aeruginosa RB in a culture containing lactic acid as a carbon source, $1 \mathrm{mM}$ selenite, and $1 \mathrm{mM}$ cadmium under various conditions. The synthesis was achieved efficiently and with high purity using the reaction conditions of $25-30{ }^{\circ} \mathrm{C}, 0.05-10 \mathrm{~g} / \mathrm{L} \mathrm{NaCl}$ in the media, and neutral $\mathrm{pH}$. Small (approximately $10 \mathrm{~nm}$ ) and large $(70-100 \mathrm{~nm})$ spherical particles were observed inside and outside the cells [30].

Fusarium oxysporum JCM11502 was also used to prepare CdSe NPs. The optimal reaction conditions used solutions of $5 \mathrm{mM} \mathrm{Cd}$ (II) and $\mathrm{Se}(\mathrm{IV})$ ions at $\mathrm{pH} 7.5$ and $25^{\circ} \mathrm{C}$. Ultrathin sections of F. oxysporum revealed that CdSe NPs were present in the intracellular space. TEM observations showed that the size of the CdSe quantum dots was less than $20 \mathrm{~nm}$. These CdSe NPs were separated and purified by gel filtration chromatography, and a single sharp FL signal indicated that the NPs has a uniform size and shape [66].

\subsection{Other Metal Nanoparticles}

Table 5 lists the microorganism strains used for the synthesis of other metal NPs and the techniques used for their characterization.

Table 5. List of microorganisms for synthesis of various metal nanoparticles and technique for confirmation of metal nanoparticles.

\begin{tabular}{|c|c|c|c|c|c|c|}
\hline Metal & Microorganism & Classification & $\begin{array}{c}\text { Active } \\
\text { Molecules }\end{array}$ & $\begin{array}{l}\text { Size } \\
(\mathrm{nm})\end{array}$ & $\begin{array}{l}\text { Techniques Used } \\
\text { for Detection }\end{array}$ & Ref. \\
\hline $\mathrm{Cu} / \mathrm{CuO}$ & Serratia sp. & bacteria & & $10-30$ & $\begin{array}{l}\text { TEM, EDS, UV-vis, } \\
\text { XRD, XPS }\end{array}$ & [38] \\
\hline $\mathrm{Cu}$ & Shewanella oneidensis & bacteria & cytochrome & $20-40$ & $\begin{array}{c}\text { TEM, STEM, } \\
\text { XANES } \\
\text { EELS, SBFSEM }\end{array}$ & [67] \\
\hline $\mathrm{Gd}_{2} \mathrm{O}_{3}$ & Lactobacillus sp. & bacteria & & $10-20$ & TEM, XRD & [68] \\
\hline $\mathrm{Fe}_{3} \mathrm{O}_{4}$ & $\begin{array}{c}\text { Thermoanaerobacter } \\
\text { ethanolicus } \\
\text { TOR-39 }\end{array}$ & bacteria & & 41.3 & $\begin{array}{l}\text { TEM, XRD, } \\
\text { zetasizer }\end{array}$ & [69] \\
\hline $\begin{array}{c}\mathrm{Pb} \\
\text {-jarosite }\end{array}$ & $\begin{array}{c}\text { Shewanella putrefaciens } \\
\text { CN32 }\end{array}$ & bacteria & & N.D. & $\begin{array}{l}\text { TEM, SEM, EDS, } \\
\text { XRD }\end{array}$ & [70] \\
\hline $\mathrm{Pb}+\mathrm{P}$ & $\begin{array}{c}\text { Shewanella sp. } \\
\text { KR-12 }\end{array}$ & bacteria & & $3 \sim 8$ & TEM, EDS & [71] \\
\hline $\mathrm{PbS}$ & Aspergillus flavus & fungi & & $35-100$ & $\begin{array}{l}\text { TEM, EDS, UV-vis, } \\
\text { FL, XRD }\end{array}$ & [72] \\
\hline $\mathrm{Pd}$ & $\begin{array}{l}\text { Shewanella sp. } \\
\text { CNZ-1 }\end{array}$ & bacteria & $\begin{array}{l}\text { hydrogenase } \\
\text { some amides }\end{array}$ & N.D. & $\begin{array}{c}\text { TEM, SEM, EDS } \\
\text { UV-vis, XRD, XPS }\end{array}$ & [73] \\
\hline $\mathrm{Pd}$ & $\begin{array}{l}\text { Enterococcus faecalis } \\
\text { CСТСС M2012445 }\end{array}$ & bacteria & $\begin{array}{l}\text { carboxyl, } \\
\text { hydroxyl } \\
\text { and amine } \\
\text { groups }\end{array}$ & N.D. & $\begin{array}{c}\text { TEM, XRD, XPS, } \\
\text { FT-IR }\end{array}$ & [74] \\
\hline $\mathrm{Pd}$ & $\begin{array}{c}\text { Desulfovibrio vulgaris } \\
\text { DSM } 644\end{array}$ & bacteria & & N.D. & TEM & [75] \\
\hline
\end{tabular}


Table 5. Cont.

\begin{tabular}{ccccccc}
\hline Metal & Microorganism & Classification & $\begin{array}{c}\text { Active } \\
\text { Molecules }\end{array}$ & $\begin{array}{c}\text { Size } \\
(\mathbf{n m})\end{array}$ & $\begin{array}{c}\text { Techniques Used } \\
\text { for Detection }\end{array}$ & Ref. \\
\hline $\mathrm{Pt}$ & $\begin{array}{c}\text { Desulfovibrio vulgaris } \\
\text { DSM 645 }\end{array}$ & bacteria & N.D. & TEM & [75] \\
\hline $\mathrm{Pt}$ & $\begin{array}{c}\text { Shewanella algae } \\
\text { ATCC 51181 }\end{array}$ & bacteria & 5 & TEM, XANES & [76] \\
\hline $\mathrm{Sb}_{2} \mathrm{O}_{3}$ & Lactobacillus sp. & bacteria & $3-12$ & TEM, XRD & [77] \\
\hline $\mathrm{Ti}$ & Lactobacillus sp. & bacteria & 40 & TEM, XRD & [17] \\
\hline $\mathrm{TiO}_{2}$ & Lactobacillus sp. & bacteria & ca. 24.6 & TEM, XRD, SAED & [78] \\
\hline $\mathrm{TiO}_{2}$ & Sachharomyces cerevisae & fungi & ca. 12.6 & TEM, XRD, SAED & [78] \\
\hline $\mathrm{ZrO}_{2}$ & Fusarium oxysporum & fungi & ca. 7.3 & TEM, XRD & [79] \\
\hline
\end{tabular}

Serratia sp. was isolated from the midgut of Stibara sp., an insect of the Cerambycidae family of beetles found in the Northwestern Ghats of India. Cells were suspended in an aqueous solution of $\mathrm{CuSO}_{4}$. XRD revealed the presence of copper oxides $\left(\mathrm{CuO}, \mathrm{Cu}_{2} \mathrm{O}\right.$, and $\left.\mathrm{Cu}_{4} \mathrm{O}_{3}\right)$ and $\mathrm{Cu}$ NPs [38].

$\mathrm{Cu}$ NPs were also synthesized by incubating a suspension of Shewanella oneidensis MR-1 with sodium lactate as an electron donor and $\mathrm{CuSO}_{4}$ in 3-(N-morpholino)propanesulfonic acid (MOPS) buffer. Ultrathin sections observed using TEM revealed that the $\mathrm{Cu}$ NPs were intracellular. Furthermore, three-dimensional electron images from serial block-face SEM revealed that the NPs were dispersed across the cells. These NPs consisted of $\mathrm{Cu}(0)$ covered by a thin $\mathrm{Cu}_{2} \mathrm{O}$ shell, which formed as a result of oxidation by air. The $\mathrm{Cu}_{2} \mathrm{O}$ shell provided the particles with good catalytic activity for azide-alkyne cycloaddition and enabled a "click chemistry" reaction [67].

Lactobacillus sp. was used to synthesize near-spherical $\mathrm{Gd}_{2} \mathrm{O}_{3}$ NPs. Gadolinium acetate was used as the source of $\mathrm{Gd}$ ions. The SAED pattern and XRD spectrum established the crystal structure of the $\mathrm{Gd}_{2} \mathrm{O}_{3}[68]$.

$\mathrm{Fe}_{3} \mathrm{O}_{4}$ NPs were synthesized using Thermoanaerobacter ethanolicus TOR-39. This thermophilic bacterial strain was incubated with glucose as an electron donor, MOPS as a pH buffer, and amorphous $\mathrm{Fe}$ (III) oxyhydroxide as an electron acceptor. A superconducting quantum interference magnetometer revealed that the $\mathrm{Fe}_{3} \mathrm{O}_{4} \mathrm{NPs}$ had higher coercivity and less remanence than those made using chemical methods [69].

Shewanella putrefaciens CN32 is a subsurface chemoautotrophic anaerobe capable of using Fe(III) during dissimilatory iron reduction. The NPs containing $\mathrm{Pb}$ and $\mathrm{P}$ detected by EDS were synthesized in a suspension of the $\mathrm{CN} 32$ cells with the mineral plumbojarosite $\left(\mathrm{PbFe}_{6}\left(\mathrm{SO}_{4}\right)_{4}(\mathrm{OH})_{12}\right)$ [70].

Lead was accumulated by Shewanella sp. KR-12 isolated from river sediment in northeast Taiwan. Notably, amorphous $\mathrm{Pb}$ NPs were synthesized when incubated with $\mathrm{Pb}(\mathrm{NO})_{3}$. Spherical particles ranged from 3-8 $\mathrm{nm}$ in size. while those on pilus-like structures emerging from bacteria ranged from $2-4 \mathrm{~nm}$. The NPs formed in linear or curved patterns within the bacteria; EDS spectra revealed that the linear localization contained elemental $\mathrm{Pb}$ and $\mathrm{P}$ [71].

Aspergillus flavus, an endophytic fungus isolated from a medicinal plant Nothapodytes foetida, tolerates lead and sulfide. PbS NPs were synthesized by incubating A. flavus in culture media containing lead acetate and sodium sulfide. The peak centered at $300 \mathrm{~nm}$ in the UV-vis spectrum, which is consistent with PbS NPs. The optical bandgap of the PbS NPs was $3.08 \mathrm{eV}$, which is markedly higher than that of the bulk PbS $(0.41 \mathrm{eV})$. The absorbance properties of the PbS NPs enabled their use for the detection of As(III) ion [72].

Pd NPs were synthesized by Shewanella sp. CNZ-1, which is an electrochemically active bacterium isolated from marine sediments. Pd NPs were synthesized on the surface of CNZ-1 cells by adding $\mathrm{Na}_{2} \mathrm{PdCl}_{4}$ and sodium lactate as an electron donor to a CNZ-1 solution. The Pd NPs catalyzed reduction of 4-nitrophenol by $\mathrm{NaBH}_{4}$. The Shewanella oneidensis MR-1 strain was also able to synthesize Pd NPs, 
but the Pd NPs synthesized by CNZ-1 were more effective than those prepared by MR-1 in mediating 4-nitrophenol reduction [73].

Pd NPs were also synthesized by incubating Enterococcus faecalis CCTCC M2012445 suspension in MOPS buffer with $\mathrm{Na}_{2} \mathrm{PdCl}_{4}$ and sodium formate as electron donor. XRD analysis revealed Pd NPs synthesis. According to TEM observation of the cell, Pd NPs were located at the cell membrane and inside the cell [74].

Desulfovibrio vulgaris DSM 644 synthesized Pt NPs and Pd NPs by incubating in MOPS buffer with $\mathrm{Na}_{2} \mathrm{PdCl}_{4}$ or $\mathrm{PtCl}_{4}$. TEM observation showed that both NPs were located on the surface and in the periplasmic space. Pt NPs synthesized by $D$. vulgaris had a high catalytic activity in pharmaceutical products removal. As pharmaceutical products are thought as one of the most alarming emergent pollutants, these Pt NPs was expected as excellent catalyst [75].

$\mathrm{Pt}$ NPs were synthesized by incubating Shewanella algae ATCC 51181 in bicarbonate buffer with $\mathrm{H}_{2} \mathrm{PtCl}_{6}$ solution and sodium lactate as electron donor under anaerobic conditions. These NPs were synthesized within $60 \mathrm{~min}$. Furthermore, these NPs were located in the periplasm. XANES spectrum of PtNPs synthesized bv S. algae was identical to the $\mathrm{Pt}(0)$, not $\mathrm{Pt}(\mathrm{IV})$ and $\mathrm{Pt}(\mathrm{II})$ [76].

Antimony chloride solution was added to Lactobacillus sp. from pharmaceutical-grade lactic acid bacillus spore tablets (SporeLac DS; Sanyko Pharmaceuticals, Japan), and the mixed solution was heated in a steam bath at $80{ }^{\circ} \mathrm{C}$ for $5-10 \mathrm{~min}$. The XRD pattern of the product was consistent with $\mathrm{n}-\mathrm{Sb}_{2} \mathrm{O}_{3}$. Williamson-Hall plots of the XRD data indicated low lattice strain. Individual $\mathrm{Sb}_{2} \mathrm{O}_{3} \mathrm{NPs}$ and a few aggregates were observed using TEM [77].

Adding a $\mathrm{TiO}_{2}$ solution to a culture solution of Lactobacillus strain generated Ti NPs. Scherrer's equation was used to estimate the average particle size from the XRD pattern [17].

$\mathrm{TiO}_{2} \mathrm{NPs}$ were synthesized by Lactobacillus sp. obtained from buttermilk. A mixture of dilute culture and $\mathrm{TiO}(\mathrm{OH})_{2}$ solution was heated on a steam bath to $60^{\circ} \mathrm{C}$ and held for $10-20 \mathrm{~min}$. After cooling, the solution was incubated at room temperature for $12-48 \mathrm{~h}$. Electron diffraction and XRD measurements established that the NPs were $\mathrm{n}-\mathrm{TiO}_{2}$ [78].

Saccharomyces cerevisiae (strain not specified) also synthesized $\mathrm{TiO}_{2} \mathrm{NPs}$. NPs formed when a $\mathrm{TiO}(\mathrm{OH})_{2}$ solution was added to an ethanoic $S$. cerevisiae solution. Electron diffraction and XRD measurements confirmed that the NPs were $\mathrm{n}-\mathrm{TiO}_{2}$ [78].

$\mathrm{ZrO}_{2} \mathrm{NPs}$ were synthesized by incubating Fusarium oxysporum in a solution of $\mathrm{K}_{2} \mathrm{ZrF}_{6}$. $\mathrm{XRD}$ measurements revealed that the $\mathrm{ZrO}_{2}$ NPs consisted of a mixture of monoclinic and tetragonal phases [79].

\section{Active Molecules in Metal Nanoparticle Synthesis by Microorganisms}

Extracellular polymeric substances (EPS) of E. coli K12 Ag NPs were synthesized by adding $\mathrm{AgNO}_{3}$ to a culture solution. Comparing the Fourier transform-infrared (FT-IR) and ${ }^{13} \mathrm{C}$ nuclear magnetic resonance (NMR) spectra of the EPS before and after reaction with $\mathrm{Ag}^{+}$revealed that the hemiacetal groups of the sugars in the EPS contributed to Ag NPs synthesis (Figure 5). The antibacterial activity of $\mathrm{Ag}^{+}$ions was mitigated because the synthesized Ag NPs in the EPS were not inside cells [36].

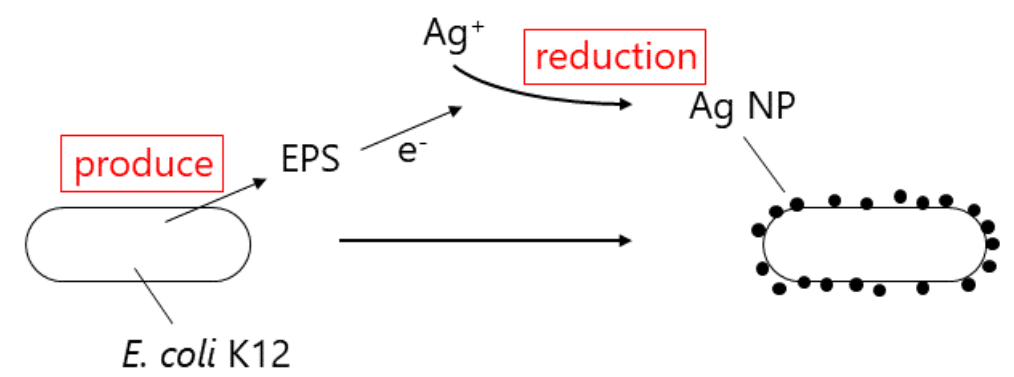

Figure 5. The mechanism of Ag NPs synthesis by E. coli K12. Extracellular polymeric substances (EPS) produced by the cell reduced Ag ion and synthesized Ag NPs. 
The synthesis of Ag NPs affected the monosaccharide composition of capsular exopolysaccharides from

Lactobacillus strains. This result suggests that different Lactobacillus strain synthesized different NPs or did not synthesize Ag NPs [40].

The FT-IR spectrum of Au NPs synthesized by the culture supernatant from A. niger NCIM 616 indicated the presence of amide linkages. This result suggested that some protein contributed to the synthesis and stabilization of the NPs [46].

The FT-IR spectrum of Au NPs synthesized by S. maltophilia AuRed02 suggests that NPs were capped with negatively charged phosphate groups from NADP. To reveal the synthesis mechanism, the CFE and the CFE with NADPH were separately mixed with $\mathrm{Au}^{3+}$. The Au NPs were synthesized only by the mixture of CFE and NADPH, indicating that an NADPH-dependent reductase enzyme in $\mathrm{CFE}$ reduced $\mathrm{Au}^{3+}$ to $\mathrm{Au}(0)$ [50].

Delftibactin, a gold-interacting nonribosomal peptide purified from D. acidovorans, was crucial to $\mathrm{Au}$ NPs synthesis by this bacterium. Mixing delftibactin and $\mathrm{AuCl}_{3}$ rapidly (within seconds) induced the synthesis of Au NPs and octahedral gold platelets at room temperature and neutral $\mathrm{pH}$. Additionally, delftibactin protected the cell from toxic soluble gold [54].

In the Au NPs synthesis by A. brasilencse, extracellular phenol-oxidizing enzymes (laccases and Mn peroxidases) acted as reducing agents [37].

Cell-free extracts from T. scotoductus SA-01 were size-fractionated by an Amicon ${ }^{\circledR}$ stirred cell fitted with a UF 30 MWCO membrane (Osmonics Inc.). Au NPs were synthesized by incubation of soluble proteins $(>30 \mathrm{kDa})$ with $\mathrm{HAuCl}_{4}$. Analysis of the $\mathrm{N}$-terminal sequence revealed that the protein synthesizing the $\mathrm{Au}$ NPs was a peptide-binding protein $\mathrm{ABC}$ transporter. The cysteine-disulfide bridge electron shuttle mechanism of the ABC transporter seemed to be involved in the Au NPs synthesis [56].

To identify the active molecules for Au NPs synthesis by B. niabensis 45, the crude peptide was analyzed by preparative high-performance liquid chromatography. Only the material corresponding to one peak was effective at synthesizing Au NPs. The results of matrix-assisted laser desorption/ionization-time of-flight mass spectrometry (MALDI-TOF-MS), electrospray ionization mass spectrometry (ESI-MS), and thin-layer chromatography (TLC) assay established that a cyclic peptide was the active agent. The cyclic peptide formed face-centered-cubic NPs with sizes ranging from 10-20 nm and formed an antibiofilm against P. aeruginosa PAO1 and S. aureus ATCC 25923 with low or no toxicity [57].

Prodigiosin was the active molecule in the synthesis of Au NPs by S. marcescens. Prodigiosin is a tripyrrole red pigment and a secondary metabolite by $S$. marcescens. Helium ion microscopy established that prodigiosin capped the Au NPs [58].

In the Au NPs synthesis by L. casei JCM 1134, glycolipids in the cell membrane and extracellular components were key molecules. Comparison of the L. casei components before and after addition of a $\mathrm{K}\left(\mathrm{AuCl}_{4}\right)$ solution revealed significantly lower unsaturated lipids level after the addition. The NMR and mass spectra revealed that diglycosyldiacylglycerol (DGDG) and triglycosyldiacylglycerol (TGDG) bearing unsaturated fatty acids were more reduced after the formation of the Au NPs. Au NPs were synthesized by DGDG purified from JCM 1134 in vitro [29]. Furthermore, the NMR and MS spectra of purified extracellular components revealed that lacto- $N$-triose and lactic acid induced the synthesis of Au NPs. Smaller NPs were synthesized by the extracellular components, indicating that these components contributed to dispersion of the particles (Figure 6) [59]

FT-IR spectrum of CFE of B. marisflavi YCIS MN 5 showed that protein existed in the CFE and the protein contributed in Au NPs synthesis. In addition, comparing FT-IR spectrum of the CFE and Au NPs synthesized by the CFE showed that the NPs were masked by the protein in CFE (Figure 7) [60]. 


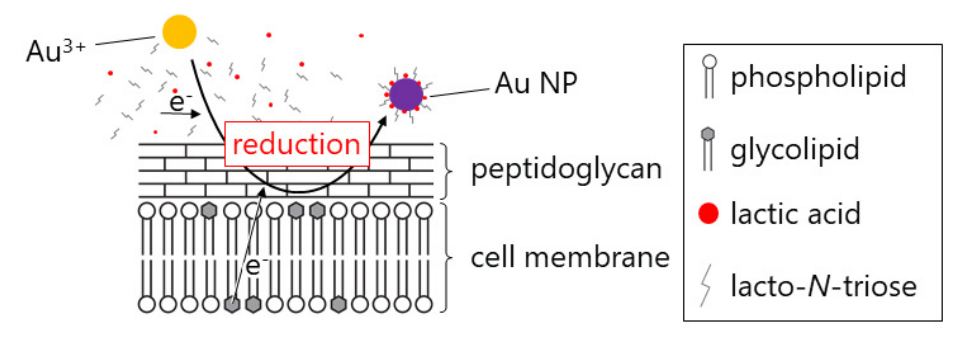

Figure 6. The mechanism of Au NPs synthesis by L. casei. Au ion was reduced by diglycosyldiacylglycerol (DGDG) (glycolipid in cell membrane) and lacto- $N$-triose. Au crystals were kept small by lactic acid secreted from the cell.

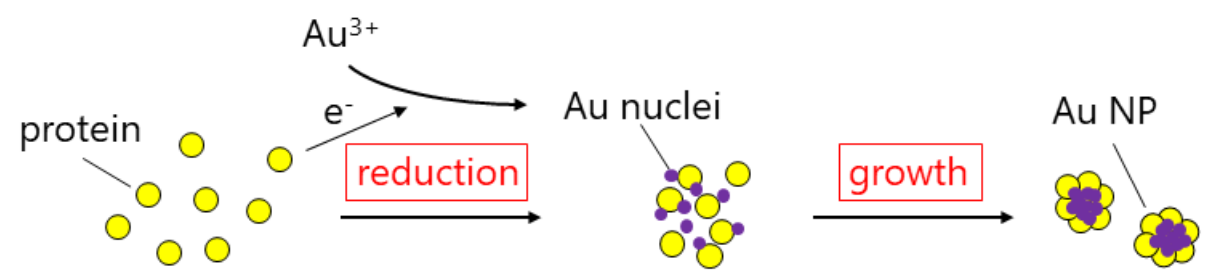

Figure 7. The mechanism of Au NPs synthesis by CFE of B. marisflavi YCIS MN 5. Protein in the CFE reduced $\mathrm{Au}$ ion and produced Au nuclei. The Au nuclei would grow to Au NP.

In the synthesis of CdSe NPs by S, cerevisiae ATCC9763, capping of the NPs with intracellular protein molecules improved dispersion in water. The presence of protein ensured that the biosynthesized NPs had much lower cytotoxicity compared with hydrothermally synthesized TGA-capped CdSe [65].

Mycelial cells were examined before and after treatment of F. oxysporum with a mixed solution of Cd(II) and Se(IV) ions to reveal the molecular dynamics of CdSe NPs synthesis. Sodium dodecyl sulfate-polyacrylamide gel electrophoresis (SDS-PAGE) established that the amount of superoxide dismutase decreased, and FL microscopy revealed that the amount of cytoplasmic superoxide increased, during the CdSe NPs synthesis. These results indicate that superoxide contributed to CdSe NPs synthesis [66].

Pd NPs were prepared by mixing a solution of live Shewanella sp. CNZ-1 cells and sodium lactate with a $\mathrm{Pd}(\mathrm{II})$ solution. Hot-killed CNZ-1 cells could not induce NPs synthesis. One or more hydrogenases were likely involved in the $\mathrm{Pd}(\mathrm{II})$ reduction by CNZ-1 in the presence of sodium lactate as an electron donor, because autoclaved bacterial cells exhibited no hydrogenase activity (Figure 8). Additionally, the FT-IR spectrum of the Pd NPs was consistent with the interaction of some amides with the Pd NPs [73].

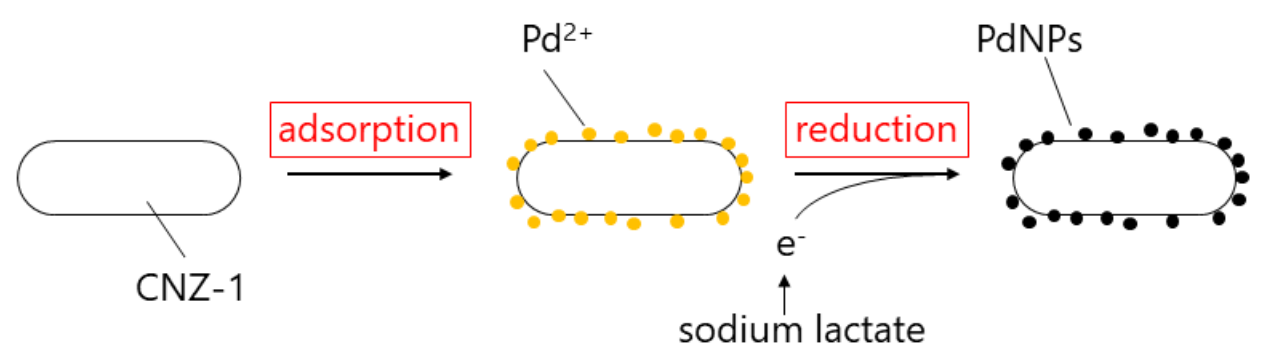

Figure 8. The mechanism of Pd NPs synthesis by Shewanella sp. CNZ-1. At first, the bacteria adsorbed $\mathrm{Pd}$ ion. The Pd ion were reduced by electron from added sodium lactate.

Although Pd NPs were synthesized by incubating E. faecalis Pd solution with sodium formate, $\mathrm{Pd}$ was not reduced without sodium formate. This result indicated that the E. faecalis cells provided a wide and uniform place for Pd NPs crystallization. The surface character of E. faecalis was revealed by XPS and FT-IR spectrum. These results showed that chemicals with carboxyl groups, hydroxyl groups, and amine groups participated in Pd recovery (Figure 9) [74]. 


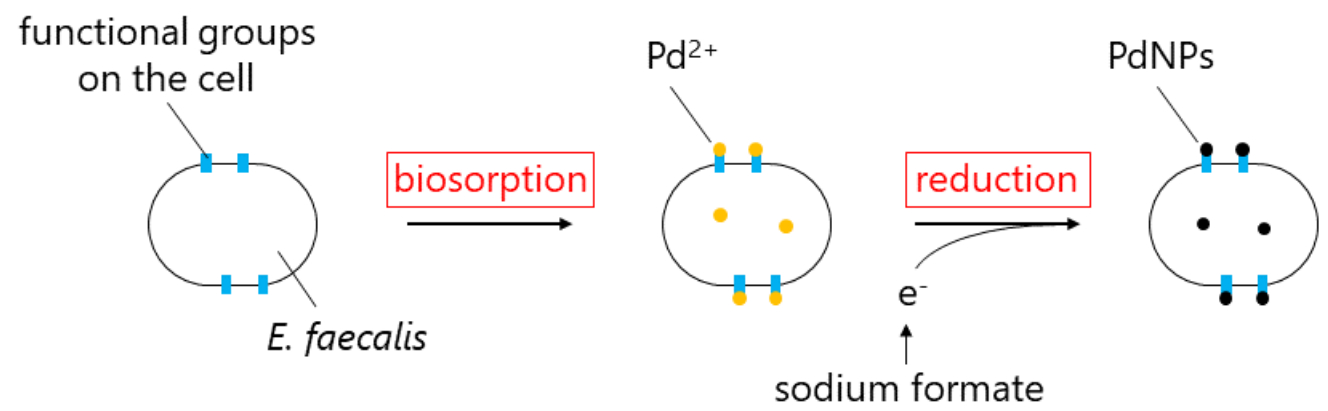

Figure 9. The mechanism of Pd NPs synthesis by E. faecalis. At first, the Pd ion was adsorbed on the cell and uptake into the cell. Carboxyl groups, hydroxyl groups, and amine groups were participated in adsorption. Next, the Pd ion was reduced. The ion donor was sodium formate.

F. oxysporum hydrolyzed $\mathrm{ZrF}_{6}{ }^{2-}$ ions to form $\mathrm{ZrO}_{2}$ NPs. Native and SDS-PAGE of the extracellular protein in the absence and presence of aqueous $\mathrm{ZrF}_{6}{ }^{2-}$ ions revealed the disappearance of proteins with molecular weights of about 24 and $28 \mathrm{kDa}$. The proteins were loaded onto a cation exchange matrix to determine the nature of the charge on the proteins. The eluted fractions hydrolyzed $\mathrm{ZrF}_{6}{ }^{2-}$, indicating that cationic proteins were involved in the $\mathrm{ZrO}_{2}$ NPs synthesis [79].

In addition, several publications have focused on the synthesis of metal NPs using genetically modified E. coli.

Au-Pd core-shell NPs were synthesized by AtPCS1-E. coli. The AtPCS1-E. coli was incubated in $\mathrm{HAuCl}_{4}$ solution, and then in $\mathrm{K}_{2} \mathrm{PdCl}_{4}$ solution. Their catalytic behavior was investigated using two methods: Chemiluminescence (CL) and benzyl alcohol oxidation (BAO). In the former, the CL of the mixture of Au-Pd NPs extracted by ultrasonication, luminol, and $\mathrm{H}_{2} \mathrm{O}_{2}$ was measured. In the BAO test, a mixture of $\mathrm{H}_{2} \mathrm{O}_{2}$, cetrimonium bromide, and Au-Pd NPs generated benzyl alcohol, benzaldehyde, and benzoic acid, which was detected using gas chromatography and mass spectrometry. These tests demonstrated that the Au-Pd NPs were catalytically active [80].

The cysteine desulfhydrase gene of Treponema denticola was over-expressed in E. coli to synthesize CdS NPs. Incubation of the cells in a culture medium supplemented with cadmium ions and cysteine resulted in CdS NPs forming on the cell wall [81].

Additionally, CdS NPs were biosynthesized via Arabidopsis thaliana phytochelatin synthase-modified E. coli (CdS/AtPCS1-E. coli). Biosynthesis of CdS NPs was greatly enhanced through expression of the AtPCS1 gene inside the E. coli cells by the pET28b vector due to the generation of phytochelatins (PCs; $\left(\gamma\right.$-Glu-Cys)n-Gly, $\mathrm{n} \geq 2$ ), which efficiently captured $\mathrm{Cd}^{2+}$ ions [82].

Tables 1-6 list the active molecules used for the synthesis of metal NPs in microorganisms.

Table 6. List of genetically modified bacteria for synthesis of metal nanoparticles and technique for confirmation of metal nanoparticles.

\begin{tabular}{lllcccc}
\hline Metal & Microorganism & Classification & $\begin{array}{c}\text { Active } \\
\text { Molecules }\end{array}$ & $\begin{array}{c}\text { Size } \\
\mathbf{( n m )}\end{array}$ & $\begin{array}{c}\text { Techniques Used for } \\
\text { Detection }\end{array}$ & Ref. \\
\hline Au-Pd & Escherichia coli & bacteria & AtPCS1 & ca. 32.3 & $\begin{array}{c}\text { TEM, SEM, UV-vis, } \\
\text { XRD }\end{array}$ & {$[80]$} \\
\hline CdS & Escherichia coli & bacteria & $\begin{array}{c}\text { cysteine } \\
\text { desulfhydrase }\end{array}$ & $<50$ & TEM, EDS & {$[81]$} \\
\hline CdS & Escherichia coli & bacteria & AtPCS1 & 35.8 & TEM, EDS, UV-vis, FL & {$[82]$} \\
\hline
\end{tabular}

\section{Purification of NPs Synthesized by Microorganisms}

A few reports have mentioned the potential applications of NPs synthesized by microorganisms. As many organic molecules from the cell components are present in the NPs solution synthesized by microorganisms, purification and isolation NPs from such contaminants are necessary for application. 
Ag NPs synthesized by E. coli were isolated by washing, dialysis, and ultracentrifugation. At first, the Ag NPs were centrifuged and resuspended by water in order to eliminate remaining Ag ion. Next, the suspension was subjected to a dialysis tube and cutoff 12,000 molecular weight. Finally, the NPs were suspended in HEPES buffer and subjected to ultracentrifugation [83].

The supernatant of Ag NPs solution synthesized by CFE of Bacillus sp. AZ1 was air dried to obtain Ag NPs. The treatment of air drying broke the cell membrane to reduce the toxicity of bacterial cells. These separated Ag NPs had antimicrobial activity for the Gram-negative (E. coli and Salmonella typhi) and Gram-positive (Staphylococcus epidermis, and Staphylococcus aureus) bacteria. Especially, these NPs had high antimicrobial activity for E. coli [75].

Pt NPs synthesized by D. vulgaris were purified by centrifugation with water and acetone to wash and drying at room temperature overnight. These purified NPs were used as catalysis for removal of pharmaceutical products (ciprofloxacin, sulfamethoxazole, ibuprofen, and $17 \beta$-estradiol). In the result, these Pt NPs had high catalytic activities to remove ciprofloxacin, sulfamethoxazole, and $17 \beta$-estradiol [84].

However, negative effects might occur by separation technique. For example, the solution color of Ag NPs synthesized by L. casei were degraded by both filtrating and centrifuging. This result suggested that Ag NPs were aggregated or entrapped in the biomass [73].

On the other hand, there are the report that assembly of bacteria and NPs promote synergy effects. The particle-bacterium assembly facilitated direct electron transfer between proteins and an electrode by immobilizing hemoglobin [42].

\section{Conclusions}

Herein, we have reviewed the synthesis of metal NPs by microorganisms. Over the last half-century, various metal NPs have been synthesized by numerous microorganisms. In some studies, the active substances for their synthesis were identified from microorganism extracts. In general, the smaller size of metal NPs shows the greater catalytic activities [14]. Genetically modified microorganisms can control the localization and amounts of activity molecules inside or outside the cell. Such genetically control methods can regulate the size and shape of metal NPs. As many biological molecules exist in the microorganism suspension, it is difficult to isolate metal NPs. However, analyses of molecular mechanisms can reveal the active molecules binding to the surface of metal NPs. If these active molecules may be useful for the applications such as biocompatibility, biomarker, and anti-cancer effects, we can use these metal NPs as high functional organic-inorganic hybrid materials.

As shown in this review, there are many reports of easy synthesis of various metal NPs by microorganisms. In addition, metal NPs synthesized by microorganisms were reported as more stable and low toxicity. Ag NPs synthesized by Staphylococcus aureus were less toxicity than chemically synthesized Ag NPs [81]. These metal NPs are biocompatible and may be useful in medical field.

Author Contributions: Conceptualization, Y.K. and M.S.; writing-original draft preparation, Y.K. and M.S.; writing-review and editing, Y.K. and M.S.; supervision, M.S.; funding acquisition, Y.K. and M.S. All authors have read and agreed to the published version of the manuscript.

Funding: This research was funded by Japan Society for the Promotion of Science (JSPS), grant number JP19H03045, JP19H05771 and JP20J13602.

Conflicts of Interest: The authors declare no conflict of interest.

\section{References}

1. Gahlawat, G.; Shikha, S.; Chaddha, B.S.; Chaudhuri, S.R.; Mayilraj, S.; Choudhury, A.R. Microbial glycolipoprotein-capped silver nanoparticles as emerging antibacterial agents against cholera. Microb. Cell Factories 2016, 15, 25. [CrossRef]

2. Kaur, A.; Gupta, U. A review on applications of nanoparticles for the preconcentration of environmental pollutants. J. Mater. Chem. 2009, 19, 8279. [CrossRef] 
3. Li, X.; Xu, H.; Chen, Z.; Chen, G. Biosynthesis of Nanoparticles by Microorganisms and Their Applications. J. Nanomater. 2011, 2011, 1-16. [CrossRef]

4. Lohse, S.E.; Murphy, C.J. Applications of colloidal inorganic nanoparticles: From medicine to energy. J. Am. Chem. Soc. 2012, 134, 15607-15620. [CrossRef]

5. Chao, J.; Liu, J.; Yu, S.; Feng, Y.; Tan, Z.; Liu, R.; Yin, Y. Speciation Analysis of Silver Nanoparticles and Silver Ions in Antibacterial Products and Environmental Waters via Cloud Point Extraction-Based Separation. Anal. Chem. 2011, 83, 6875-6882. [CrossRef]

6. Storhoff, J.J.; Lazarides, A.A.; Mucic, R.C.; Mirkin, C.A.; Letsinger, R.L.; Schatz, G.C. What Controls the Optical Properties of DNA-Linked Gold Nanoparticle Assemblies? J. Am. Chem. Soc. 2000, 122, 4640-4650. [CrossRef]

7. Deplanche, K.; Bennett, J.A.; Mikheenko, I.P.; Omajali, J.; Wells, A.S.; Meadows, R.E.; Wood, J.; Macaskie, L.E. Catalytic activity of biomass-supported Pd nanoparticles: Influence of the biological component in catalytic efficacy and potential application in 'green' synthesis of fine chemicals and pharmaceuticals. Appl. Catal. B Environ. 2014, 147, 651-665. [CrossRef]

8. Jukk, K.; Kongi, N.; Matisen, L.; Kallio, T.; Kontturi, K.; Tammeveski, K. Electroreduction of oxygen on palladium nanoparticles supported on nitrogen-doped graphene nanosheets. Electrochim. Acta 2014, 137, 206-212. [CrossRef]

9. Safavi, A.; Maleki, N.; Farjami, F.; Farjami, E. Electrocatalytic oxidation of formaldehyde on palladium nanoparticles electrodeposited on carbon ionic liquid composite electrode. J. Electroanal. Chem. 2009, 626, 75-79. [CrossRef]

10. García-Domínguez, P.; Nevado, C. Au-Pd bimetallic catalysis: The importance of anionic ligands in catalyst speciation. J. Am. Chem. Soc. 2016, 138, 3266-3269. [CrossRef]

11. Xu, J.; White, T.; Li, P.; He, C.; Yu, J.; Yuan, W.; Han, Y. Biphasic Pd-Au alloy catalyst for low-temperature CO oxidation. J. Am. Chem. Soc. 2010, 132, 10398-10406. [CrossRef]

12. Cheong, S.; Graham, L.; Brett, G.L.; Henning, A.M.; Watt, J.; Miedziak, P.J.; Song, M.; Takeda, Y.; Taylor, S.H.; Tilley, R.D. Au-Pd core-Shell nanoparticles as alcohol oxidation catalysts: Effect of shape and composition. ChemSusChem 2013, 6, 1858-1862. [CrossRef]

13. Su, R.; Tiruvalam, R.; He, Q.; Dimitratos, N.; Kesavan, L.; Hammond, C.; Lopez-Sanchez, J.A.; Bechstein, R.; Kiely, C.J.; Hutchings, G.J. Promotion of phenol photodecomposition over $\mathrm{TiO}_{2}$ using $\mathrm{Au}$, Pd, and $\mathrm{Au}-\mathrm{Pd}$ nanoparticles. ACS Nano 2012, 6, 6284-6292. [CrossRef] [PubMed]

14. Hamasaki, T.; Kashiwagi, T.; Imada, T.; Nakamichi, N.; Aramaki, S.; Toh, K.; Morisawa, S.; Shimakoshi, H.; Hisaeda, Y.; Shirahata, S. Kinetic Analysis of Superoxide Anion Radical-Scavenging and Hydroxyl Radical-Scavenging Activities of Platinum Nanoparticles. Langmuir 2008, 24, 7354-7364. [CrossRef]

15. Jin, T.; Yan, M.; Yamamoto, Y. Click Chemistry of Alkyne-Azide Cycloaddition using Nanostructured Copper Catalysts. Chem CatChem 2012, 4, 1217-1229. [CrossRef]

16. Kessler, R. Engineered Nanoparticles in Consumer Products: Understanding a New Ingredient. Environ. Health Perspect. 2011, 119, A120-A125. [CrossRef]

17. Prasad, K.; Jha, A.; Kulkarni, A. Lactobacillus assisted synthesis of titanium nanoparticles. Nanoscale Res. Lett. 2007, 2, 248-250. [CrossRef]

18. Prasad, K.; Jha, A.K. Biosynthesis of CdS nanoparticles: An improved green and rapid procedure. J. Colloid Interface Sci. 2010, 342, 68-72. [CrossRef] [PubMed]

19. Compeán-Jasso, M.E.; Ruiz, F.; Martínez, J.R.; Herrera-Gómez, A. Magnetic properties of magnetite nanoparticles synthesized by forced hydrolysis. Mater. Lett. 2008, 62, 4248-4250. [CrossRef]

20. Kim, H.; Kang, Y.; Park, H.; Lee, K.; Yang, S.; Jung, H.; Seo, D. Effects of the dispersion of zirconium dioxide nanoparticles on high performance electro-optic properties in liquid crystal devices. Liquid Cryst. 2011, 38, 871-875. [CrossRef]

21. Trindade, T.; O’Brien, P.; Pickett, N.L. Nanocrystalline Semiconductors: Synthesis, Properties, and Perspectives. Chem. Mater. 2001, 13, 3843-3858. [CrossRef]

22. Faraon, A.; Englund, D.; Fushman, I.; Vučković, J.; Stoltz, N.; Petroff, P. Local quantum dot tuning on photonic crystal chips. Appl. Phys. Lett. 2007, 90, 213110. [CrossRef]

23. Muthalif, M.P.A.; Sunesh, C.D.; Choe, Y. Enhanced light absorption and charge recombination control in quantum dot sensitized solar cells using tin doped cadmium sulfide quantum dots. J. Colloid Interface Sci. 2019, 534, 291-300. [CrossRef] [PubMed] 
24. Wang, D.; Li, X.; Zheng, L.; Qin, L.; Li, S.; Ye, P.; Li, Y.; Zou, J. Size-controlled synthesis of CdS nanoparticles confined on covalent triazine-based frameworks for durable photocatalytic hydrogen evolution under visible light. Nanoscale 2018, 10, 19509-19516. [CrossRef] [PubMed]

25. Frens, G. Controlled Nucleation for the Regulation of the Particle Size in Monodisperse Gold Suspensions. Nat. Phys. Sci. 1973, 241, 20-22. [CrossRef]

26. Murray, C.; Norris, D.J.; Bawendi, M.G. Synthesis and characterization of nearly monodisperse CdE ( $\mathrm{E}=$ sulfur, selenium, tellurium) semiconductor nanocrystallites. J. Am. Chem. Soc. 1993, 115, 8706-8715. [CrossRef]

27. Blakemore, R. Magnetotactic bacteria. Science 1975, 190, 377-379. [CrossRef]

28. Korbekandi, H.; Iravani, S.; Abbasi, S. Optimization of biological synthesis of silver nanoparticles using Lactobacillus casei subsp. casei. J. Chem. Technol. Biotechnol. 2012, 87, 932-937. [CrossRef]

29. Kikuchi, F.; Kato, Y.; Furihata, K.; Kogure, T.; Imura, Y.; Yoshimura, E.; Suzuki, M. Formation of gold nanoparticles by glycolipids of Lactobacillus casei. Sci. Rep. 2016, 6, 34626. [CrossRef]

30. Ayano, H.; Kuroda, M.; Soda, S.; Ike, M. Effects of culture conditions of Pseudomonas aeruginosa strain RB on the synthesis of CdSe nanoparticles. J. Biosci. Bioeng. 2015, 119, 440-445. [CrossRef]

31. Bruins, M.R.; Kapil, S.; Oehme, F.W. Microbial resistance to metals in the environment. Ecotoxicol. Environ. Saf. 2000, 45, 198-207. [CrossRef] [PubMed]

32. Park, J.H.; Lamb, D.; Paneerselvam, P.; Choppala, G.; Bolan, N.; Chung, J. Role of organic amendments on enhanced bioremediation of heavy metal (loid) contaminated soils. J. Hazard. Mater. 2011, 185, 549-574. [CrossRef]

33. Konishi, Y.; Tsukiyama, T.; Ohno, K.; Saitoh, N.; Nomura, T.; Nagamine, S. Intracellular recovery of gold by microbial reduction of $\mathrm{AuCl}_{4}{ }^{-}$ions using the anaerobic bacterium Shewanella algae. Hydrometallurgy 2006, 81, 24-29. [CrossRef]

34. Joerger, R.; Klaus, T.; Granqvist, C.G. Biologically Produced Silver-Carbon Composite Materials for Optically Functional Thin-Film Coatings. Adv. Mater. 2000, 12, 407-409. [CrossRef]

35. Ahmad, A.; Senapati, S.; Khan, M.I.; Kumar, R.; Ramani, R.; Srinivas, V.; Sastry, M. Intracellular synthesis of gold nanoparticles by a novel alkalotolerant actinomycete, Rhodococcus species. Nanotechnology 2003, 14, 824. [CrossRef]

36. Kang, F.; Alvarez, P.J.; Zhu, D. Microbial Extracellular Polymeric Substances Reduce Ag+ to Silver Nanoparticles and Antagonize Bactericidal Activity. Environ. Sci. Technol. 2014, 48, 316-322. [CrossRef] [PubMed]

37. Kupryashina, M.; Vetchinkina, E.; Burov, A.; Ponomareva, E.; Nikitina, V. Biosynthesis of gold nanoparticles by Azospirillum brasilense. Microbiology 2013, 82, 833-840. [CrossRef]

38. Hasan, S.; Singh, S.; Parikh, R.Y.; Dharne, M.S.; Patole, M.S.; Prasad, B.L.V.; Shouche, Y.S. Bacterial Synthesis of Copper/Copper Oxide Nanoparticles. J. Nanosci. Nanotechnol. 2008, 8, 3191-3196. [CrossRef]

39. Ahmad, A.; Mukherjee, P.; Senapati, S.; Mandal, D.; Khan, M.I.; Kumar, R.; Sastry, M. Extracellular biosynthesis of silver nanoparticles using the fungus Fusarium oxysporum. Colloids Surf. B Biointerfaces 2003, 28, 313-318. [CrossRef]

40. Garmasheva, I.; Kovalenko, N.; Voychuk, S.; Ostapchuk, A.; Livins'ka, O.; Oleschenko, L. Lactobacillus species mediated synthesis of silver nanoparticles and their antibacterial activity against opportunistic pathogens in vitro. BioImpacts BI 2016, 6, 219-223. [CrossRef]

41. Sani, N.J.; Aminu, B.M.; Mukhtar, M.D. Eco-friendly synthesis of silver nanoparticles using Lactobacillus delbrueckii subsp. bulgaricus isolated from kindrimo (locally fermented milk) in Kano State, Nigeria. Bayero J. Pure Appl. Sci. 2018, 10, 481. [CrossRef]

42. Du, L.; Jiang, H.; Liu, X.; Wang, E. Biosynthesis of gold nanoparticles assisted by Escherichia coli DH5 $\alpha$ and its application on direct electrochemistry of hemoglobin. Electrochem. Commun. 2007, 9, 1165-1170. [CrossRef]

43. He, S.; Guo, Z.; Zhang, Y.; Zhang, S.; Wang, J.; Gu, N. Biosynthesis of gold nanoparticles using the bacteria Rhodopseudomonas capsulata. Mater. Lett. 2007, 61, 3984-3987. [CrossRef]

44. He, S.; Zhang, Y.; Guo, Z.; Gu, N. Biological Synthesis of Gold Nanowires Using Extract of Rhodopseudomonas capsulata. Biotechnol. Prog. 2008, 24, 476-480. [CrossRef] 
45. Konishi, Y.; Tsukiyama, T.; Tachimi, T.; Saitoh, N.; Nomura, T.; Nagamine, S. Microbial deposition of gold nanoparticles by the metal-reducing bacterium Shewanella algae. Electrochim. Acta 2007, 53, $186-192$. [CrossRef]

46. Bhambure, R.; Bule, M.; Shaligram, N.; Kamat, M.; Singhal, R. Extracellular Biosynthesis of Gold Nanoparticles using Aspergillus niger-Its Characterization and Stability. Chem. Eng. Technol. 2009, 32, 1036-1041. [CrossRef]

47. Reith, F.; Etschmann, B.; Grosse, C.; Moors, H.; Benotmane, M.; Monsieurs, P.; Grass, G.; Doonan, C.; Vogt, S.; Lai, B.; et al. Mechanisms of gold biomineralization in the bacterium Cupriavidus metallidurans. Proc. Natl. Acad. Sci. USA 2009, 106, 17757. [CrossRef]

48. Das, S.K.; Das, A.R.; Guha, A.K. Gold Nanoparticles: Microbial Synthesis and Application in Water Hygiene Management. Langmuir 2009, 25, 8192-8199. [CrossRef]

49. Kalishwaralal, K.; Deepak, V.; Ram Kumar Pandian, S.; Gurunathan, S. Biological synthesis of gold nanocubes from Bacillus licheniformis. Bioresour. Technol. 2009, 100, 5356-5358. [CrossRef]

50. Nangia, Y.; Wangoo, N.; Goyal, N.; Shekhawat, G.; Suri, C.R. A novel bacterial isolate Stenotrophomonas maltophilia as living factory for synthesis of gold nanoparticles. Microb. Cell Factories 2009, 8, 39. [CrossRef]

51. Mishra, A.; Bhadauria, S.; Gaur, M.; Pasricha, R. Extracellular microbial synthesis of gold nanoparticles using fungus Hormoconis resinae. JOM 2010, 62, 45-48. [CrossRef]

52. Sharma, N.; Pinnaka, A.K.; Raje, M.; Fnu, A.; Bhattacharyya, M.S.; Choudhury, A.R. Exploitation of marine bacteria for production of gold nanoparticles. Microb. Cell Factories 2012, 11, 86. [CrossRef]

53. Markus, J.; Mathiyalagan, R.; Kim, Y.; Abbai, R.; Singh, P.; Ahn, S.; Perez, Z.E.J.; Hurh, J.; Yang, D.C. Intracellular synthesis of gold nanoparticles with antioxidant activity by probiotic Lactobacillus kimchicus DCY51T isolated from Korean kimchi. Enzym. Microb. Technol. 2016, 95, 85-93. [CrossRef]

54. Johnston, C.W.; Wyatt, M.A.; Li, X.; Ibrahim, A.; Shuster, J.; Southam, G.; Magarvey, N.A. Gold biomineralization by a metallophore from a gold-associated microbe. Nat. Chem. Biol. 2013, 9, 241-243. [CrossRef] [PubMed]

55. Prakash, D.; Mahale, V.; Bankar, A.; Nawani, N.; Mahale, V. Biosynthesis of colloidal gold nanoparticles by Streptomyces sp. NK52 and its anti-lipid peroxidation activity. Indian J. Exp. Biol. 2013, 51, 969.

56. Erasmus, M.; Cason, E.; Cason, E.; van Marwijk, J.; van Marwijk, J.; Botes, E.; Botes, E.; Gericke, M.; Gericke, M.; van Heerden, E.; et al. Gold nanoparticle synthesis using the thermophilic bacterium Thermus scotoductus SA-01 and the purification and characterization of its unusual gold reducing protein. Gold Bull. 2014, 47, 245-253. [CrossRef]

57. Li, Y.; Li, Y.; Li, Q.; Fan, X.; Gao, J.; Luo, Y. Rapid Biosynthesis of Gold Nanoparticles by the Extracellular Secretion of Bacillus niabensis 45: Characterization and Antibiofilm Activity. J. Chem. 2016, 2016, 1-7. [CrossRef]

58. Dozie-Nwachukwu, S.; Obayemi, J.; Danyuo, Y.; Etuk-Udo, G.; Chi, Y.; Hu, J.; Anuku, N.; Odusanya, O.; Malatesta, K.; Soboyejo, W. Biosynthesis of Gold Nanoparticles and Gold/Prodigiosin Nanoparticles with Serratia marcescens Bacteria. Waste Biomass Valor 2017, 8, 2045-2059. [CrossRef]

59. Kato, Y.; Yoshimura, E.; Suzuki, M. Synthesis of Gold Nanoparticles by Extracellular Components of Lactobacillus casei. ChemistrySelect 2019, 4, 7331-7337. [CrossRef]

60. Nadaf, N.Y.; Kanase, S.S. Biosynthesis of gold nanoparticles by Bacillus marisflavi and its potential in catalytic dye degradation. Arab. J. Chem. 2019, 12, 4806-4814. [CrossRef]

61. Sweeney, R.Y.; Mao, C.; Gao, X.; Burt, J.L.; Belcher, A.M.; Georgiou, G.; Iverson, B.L. Bacterial Biosynthesis of Cadmium Sulfide Nanocrystals. Chem. Biol. 2004, 11, 1553-1559. [CrossRef] [PubMed]

62. Bai, H.J.; Zhang, Z.M.; Guo, Y.; Yang, G.E. Biosynthesis of cadmium sulfide nanoparticles by photosynthetic bacteria Rhodopseudomonas palustris. Colloids Surf. B Biointerfaces 2009, 70, 142-146. [CrossRef] [PubMed]

63. Cui, R.; Liu, H.; Xie, H.; Zhang, Z.; Yang, Y.; Pang, D.; Xie, Z.; Chen, B.; Hu, B.; Shen, P. Living Yeast Cells as a Controllable Biosynthesizer for Fluorescent Quantum Dots. Adv. Funct. Mater. 2009, 19, $2359-2364$. [CrossRef]

64. Suresh, A.K. Extracellular bio-production and characterization of small monodispersed CdSe quantum dot nanocrystallites. Spectrochim. Acta Part A Mol. Biomol. Spectrosc. 2014, 130, 344-349. [CrossRef] [PubMed]

65. Wu, S.; Su, Y.; Liang, R.; Ai, X.; Qian, J.; Wang, C.; Chen, J.; Yan, Z. Crucial factors in biosynthesis of fluorescent CdSe quantum dots in Saccharomyces cerevisiae. RSC Adv. 2015, 5, 79184-79191. [CrossRef] 
66. Yamaguchi, T.; Tsuruda, Y.; Furukawa, T.; Negishi, L.; Imura, Y.; Sakuda, S.; Yoshimura, E.; Suzuki, M. Synthesis of CdSe Quantum Dots Using Fusarium oxysporum. Materials 2016, 9, 855. [CrossRef]

67. Kimber, R.L.; Lewis, E.A.; Parmeggiani, F.; Smith, K.; Bagshaw, H.; Starborg, T.; Joshi, N.; Figueroa, A.I.; van der Laan, G.; Cibin, G.; et al. Biosynthesis and Characterization of Copper Nanoparticles Using Shewanella oneidensis: Application for Click Chemistry. Small 2018, 14, 1703145. [CrossRef]

68. Jha, A.K.; Prasad, K.; Kulkarni, A.R. Synthesis of $\mathrm{Gd}_{2} \mathrm{O}_{3}$ nanoparticles using Lactobacillus sp.: A novel green approach. Int. J. Green Nanotechnol. Phys. Chem. 2010, 2, 31-38. [CrossRef]

69. Yeary, L.W.; Ji-Won, M.; Love, L.J.; Thompson, J.R.; Rawn, C.J.; Phelps, T.J. Magnetic properties of biosynthesized magnetite nanoparticles. TMAG 2005, 41, 4384-4389. [CrossRef]

70. Smeaton, C.M.; Fryer, B.J.; Weisener, C.G. Intracellular Precipitation of Pb by Shewanella putrefaciens CN32 during the Reductive Dissolution of Pb-Jarosite. Environ. Sci. Technol. 2009, 43, 8086-8091. [CrossRef]

71. Liu, C.; Liu, C.; Yen, J.; Yen, J. Characterization of lead nanoparticles formed by Shewanella sp. KR-12. J. Nanopart. Res. 2016, 18, 1-10. [CrossRef]

72. Priyanka, U.; Akshay, G.; Elisha, M.; Surya, T.; Nitish, N.; Raj, M. Biologically synthesized PbS nanoparticles for the detection of arsenic in water. Int. Biodeterior. Biodegrad. 2017, 119, 78-86.

73. Zhang, H.; Hu, X. Rapid production of Pd nanoparticle by a marine electrochemically active bacterium Shewanella sp. CNZ-1 and its catalytic performance on 4-nitrophenol reduction. RSC Adv. 2017, 7, 41182-41189. [CrossRef]

74. Cui, J.; Zhu, N.; Kang, N.; Ha, C.; Shi, C.; Wu, P. Biorecovery mechanism of palladium as nanoparticles by Enterococcus faecalis: From biosorption to bioreduction. Chem. Eng. J. 2017, 328, 1051-1057. [CrossRef]

75. Martins, M.; Mourato, C.; Sanches, S.; Noronha, J.P.; Crespo, M.T.B.; Pereira, I.A.C. Biogenic platinum and palladium nanoparticles as new catalysts for the removal of pharmaceutical compounds. Water Res. 2017, 108, 160-168. [CrossRef]

76. Konishi, Y.; Ohno, K.; Saitoh, N.; Nomura, T.; Nagamine, S.; Hishida, H.; Takahashi, Y.; Uruga, T. Bioreductive deposition of platinum nanoparticles on the bacterium Shewanella algae. J. Biotechnol. 2007, 128, 648-653. [CrossRef]

77. Jha, A.K.; Prasad, K.; Prasad, K. Biosynthesis of $\mathrm{Sb}_{2} \mathrm{O}_{3}$ nanoparticles: A low-cost green approach. Biotechnol. J. 2009, 4, 1582-1585. [CrossRef]

78. Jha, A.K.; Prasad, K.; Kulkarni, A.R. Synthesis of $\mathrm{TiO}_{2}$ nanoparticles using microorganisms. Colloids Surf. $B$ Biointerfaces 2009, 71, 226-229. [CrossRef]

79. Bansal, V.; Rautaray, D.; Ahmad, A.; Sastry, M. Biosynthesis of zirconia nanoparticles using the fungus Fusarium oxysporum. J. Mater. Chem. 2004, 14, 333-335. [CrossRef]

80. Zhang, D.; Tang, D.; Yamamoto, T.; Kato, Y.; Horiuchi, S.; Ogawa, S.; Yoshimura, E.; Suzuki, M. Improving biosynthesis of AuPd core-shell nanoparticles through Escherichia coli with the assistance of phytochelatin for catalytic enhanced chemiluminescence and benzyl alcohol oxidation. J. Inorg. Biochem. 2019, 199, 110795. [CrossRef]

81. Wang, C.; Lum, A.; Ozuna, S.; Clark, D.; Keasling, J. Aerobic sulfide production and cadmium precipitation by Escherichia coli expressing the Treponema denticola cysteine desulfhydrase gene. Appl. Microbiol. Biotechnol. 2001, 56, 425-430. [CrossRef] [PubMed]

82. Zhang, D.; Yamamoto, T.; Tang, D.; Kato, Y.; Horiuchi, S.; Ogawa, S.; Yoshimura, E.; Suzuki, M. Enhanced biosynthesis of CdS nanoparticles through Arabidopsis thaliana phytochelatin synthase-modified Escherichia coli with fluorescence effect in detection of pyrogallol and gallic acid. Talanta 2019, 195, 447-455. [CrossRef] [PubMed]

83. Gurunathan, S.; Kalishwaralal, K.; Vaidyanathan, R.; Venkataraman, D.; Pandian, S.R.K.; Muniyandi, J.; Hariharan, N.; Eom, S.H. Biosynthesis, purification and characterization of silver nanoparticles using Escherichia coli. Colloids Surf. B Biointerfaces 2009, 74, 328-335. [CrossRef] [PubMed]

84. Deljou, A.; Goudarzi, S. Green Extracellular Synthesis of the Silver Nanoparticles Using Thermophilic Bacillus Sp. AZ1 and its Antimicrobial Activity against Several Human Pathogenetic Bacteria. Iran. J. Biotechnol. 2016, 14, 25-32. [CrossRef] [PubMed]

(C) 2020 by the authors. Licensee MDPI, Basel, Switzerland. This article is an open access article distributed under the terms and conditions of the Creative Commons Attribution (CC BY) license (http://creativecommons.org/licenses/by/4.0/). 